Article

\title{
A Cross-Country Comparison of Sustainable Energy Development in Selected EU Members
}

\author{
Claudia Kettner ${ }^{1}$, Daniela Kletzan-Slamanig ${ }^{1, *}$, Angela Köppl ${ }^{1}$, Beate Littig ${ }^{2}$, \\ Irina Zielinska ${ }^{2}$ \\ 1 Austrian Institute of Economic Research (WIFO), Arsenal Objekt 20, 1030 \\ Vienna, Austria \\ 2 Institute for Advanced Studies (IHS), Josefstädter Str. 39, 1080 Vienna, Austria \\ * Correspondence: Daniela Kletzan-Slamanig, Email: kletzan@wifo.ac.at; \\ Tel.: +43-1-798-26-01-274.
}

\begin{abstract}
Two major international frameworks provide landmarks for future development paths: the UN Sustainable Development Goals (SDGs) and the Paris Climate Agreement. Monitoring the progress towards achieving the individual goals must take into account a multitude of synergies and tradeoffs. In this paper we use composite indices to analyze climate and energy policies in selected EU member countries. These results show that, in general, the improvements regarding energy efficiency, emissions and deployment of renewables have been moderate in the period under observation (2005-2015). This hints at the time needed for restructuring to take place, which underlines the importance of credible political commitments to climate targets, the implementation of ambitious instruments and the need for stability in the guiding frameworks to effectuate substantial changes. In addition, the analysis of the selected countries shows that they are characterized by very specific energy systems (complemented by specific social structures), and this determines the challenges that each country must overcome on the way to decarbonization and sustainable development. While the SDGs are to be implemented on a global scale, it is necessary to adapt them to the characteristics of a given country or region. Reliable and long-term quantitative data that is comparable across countries or regions and that takes into account the social dimension is required to be able to monitor the overall progress of SGD implementation.
\end{abstract}

\section{G Open Access}

Received: 09 May 2019

Accepted: 24 September 2019

Published: 10 October 2019

Copyright (C) 2019 by the author(s). Licensee Hapres, London, United Kingdom. This is an open access article distributed under the terms and conditions of Creative Commons Attribution 4.0 International License.

KEYWORDS: sustainable development; composite indices; energy policy; climate policy; cross-country comparison; EU Member States

\section{INTRODUCTION}

In 2015, two major international agreements were reached that provide landmarks for the development paths that countries should follow until 2030 or 2050: the UN Sustainable Development Goals (SDGs) and the 
Paris Climate Agreement. Both sets of (long-term) targets require a fundamental restructuring of economies and societies.

The SDGs were devised as "a universal agenda of sustainable development, calling on all nations to pursue a holistic strategy that combines economic development, social inclusion and environmental sustainability" [1]. The resolution "Transforming our world: the Agenda 2030 for Sustainable Development" [2], which was adopted by the General Assembly of the United Nations on 21 October 2015 and which served as a reference for the Paris Climate Summit, has provided the Sustainable Development Goals (SDG) as a strategy that on the one hand systematically links climate with well-being, environmental goals, and social policy, and on the other hand provides a practice-oriented differentiation into a complex set of sub-goals and the determination of relevant indicators to keep track of their status.

The complexity and ambition of these goals pose a challenge to research and policy analysis as well as to policy-making and implementation. In addition to monitoring the progress toward achieving the individual goals, a multitude of synergies and trade-offs must be considered. In many cases there will be synergies and co-benefits for other targets if one is achieved [3,4]. However, especially when there is no integrated view on the whole set of targets, unintended adverse sideeffects (e.g., lock-ins) might occur. Extended information and measurement systems are called for to structure the high degree of complexity implicated by the multidimensionality of sustainable development (for further discussion of fundamental controversies related to the conception, as well as to the practical and political implementation of sustainability issues, see Littig and Griessler [5]) and to highlight the interdependencies between various issues.

In this paper we use a set of indices that represent two SDGs to analyze climate and energy policies for selected European countries. Each composite index is based on a multitude of indicators covering the three dimensions of sustainable development. We put energy services instead of energy flows at the center of our approach, as these are the relevant determinants for well-being [6-12]. Based on a comprehensive view of the energy system, we calculate composite indices considering five sectors: households, manufacturing, services, transport, and electricity and heat supply. This approach allows us to carry out cross-country comparisons of energy sustainability combining the economic, environmental and social dimensions of sustainability with a sectoral perspective. Nine countries are selected and compared with regard to their status of sustainable energy development. In addition, their development over time is assessed and the specific drivers are discussed.

The paper is structured as follows: The second section describes the context of the SDGs and our approach to developing climate and energy policy indicators. The third section presents the methodological approach used to calculate the composite indices and select countries. After this, the 
results of the cross-country comparison based on the composite indices are presented and discussed. The paper ends with conclusions in the final section. Additionally, in order to embed the results that were gained through the composite indices for sustainable energy development in a wider context, data and exemplary details of the energy and climate policy background for selected countries-Denmark, Sweden, France and Poland-are presented in the Appendices.

\section{CLIMATE AND ENERGY POLICY INDICATORS IN THE CONTEXT OF THE UN SDGS}

Assessing the SDGs is a challenging and not well-defined task, as is documented by the emerging literature. Different scientific approaches and exploratory studies acknowledge the lack of broadly agreed measurement concepts [13]. In the literature, different perspectives on the SDGs are taken: in terms of geographical coverage they range from global or multi-country assessments $[14,15]$ to regional or local perspectives [16-19]. Furthermore, different aspects are captured, e.g., focusing on specific goals [20-23] or discussing the usefulness and shortcomings of specific indicators in the context of the SDGs [13,24].

Another strand of research focuses on the manifold interactions between the 17 SDGs and different sub-targets [4,25-32]. Taking into account the interdependencies is highly relevant, as omitting synergies and trade-offs from the assessment and planning processes related to reaching individual SDGs bears the risk of sub-optimal or even perverse outcomes. This not only applies to the total set of SDGs but also to the subset of energy and climate policy indicators described below, as can be illustrated by the example of policies for reducing energy expenditures of poor households (thus contributing to improvements in the social dimension/SDG 10) that subsequently might increase energy demand and in turn emissions (with negative effects on the environmental dimension/SDG 13), if not properly designed.

The socio-ecological framework proposed here aims at capturing the complexity of the SDGs in a coherent conceptual framework with a focus on wellbeing and embedding the energy system in this broader context. The indicators used for calculating the composite indices in this paper therefore focus specifically on two goals-"Affordable and clean energy" (SDG 7) and "Climate Action" (SDG 13)—and comprise operational indicators that emphasize the role of energy services instead of energy flows in generating well-being. The conceptual starting point is energy services in four demand-side sectors (residential buildings, transport, manufacturing and services). In addition, consistent indicators for sustainable electricity and heat supply are included.

Figure 1A,B illustrates the socio-ecological concept to which our research is related. Similar to other research that uses a "doughnut" visualization [4,33] (for an overview of these approaches see Breuer [30]), we assign the SDGs to three layers: wellbeing, governance and planetary 
boundaries. This illustration (Figure 2A) represents the space in which sustainable development can be achieved, in the sense that social goals are met while the integrity of ecosystems is simultaneously preserved. According to our representation [34], ten SDGs are attributed to the layer of well-being. These are embedded in governance structures (including three SDGs) that constitute the supporting framework for well-being. The outermost layer comprises the planetary boundaries representing the biophysical base as well as the natural limits for all societal processes.

Figure 2B illustrates how the energy system approach of our indicator set relates to this socio-ecological framework and the SDGs. While the issues of energy and climate change pertain to the layer of "planetary boundaries", the energy services that we focus on are a fundamental aspect of "well-being". The generation of energy services by combining different capital stocks and energy flows is essential for economic and social development. The quantity of energy services required is determined by economic activity, income and individual preferences (for a description on this approach see Köppl et al. [11]). The energy demand for providing energy services depends on the application and transformation technologies used. In buildings, for example, the energy required to deliver comfortable room temperature depends on the thermal quality of the building as well as the heating system.

(A) Embedding the SDGs into the broader socioecological context

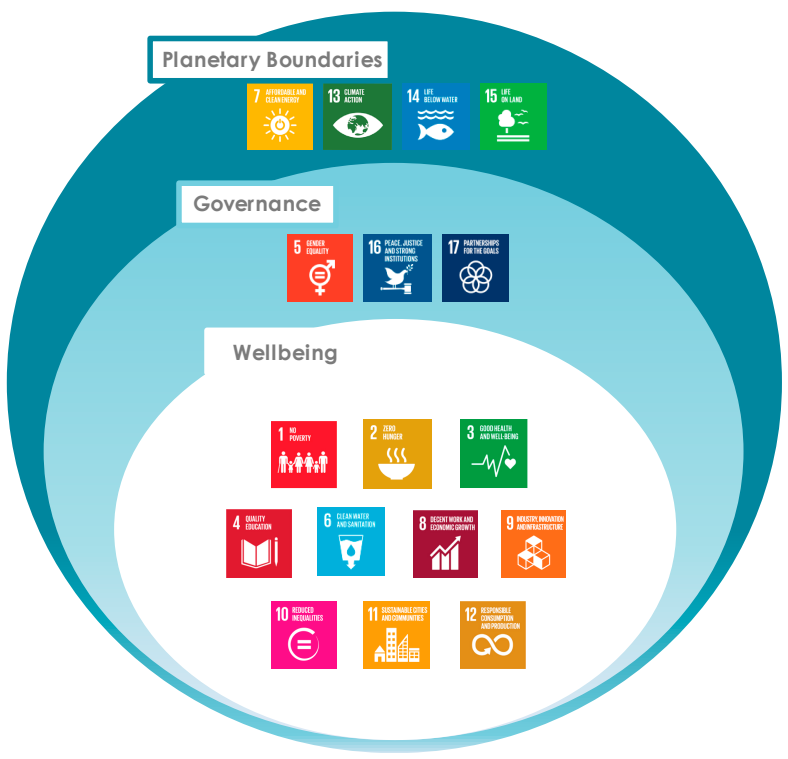

(B) Embedding the ClEP indicator approach into the broader socio-ecological context

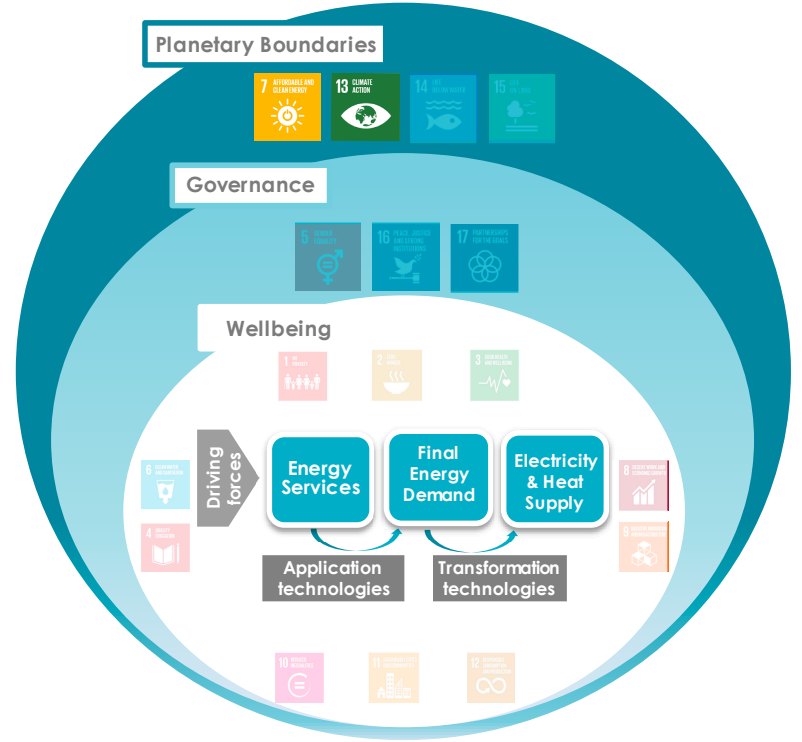

Figure 1. Socio-ecological context. Reproduced with permission from [34], copyright @ 2018 Austrian Institute of Economic Research.

\section{METHOD AND DATA}

Starting from the energy service perspective on the energy system as described above, we calculate two sets of composite indices that illustrate the sustainability of energy use and supply and allow for cross-country 
comparisons of energy or climate policy. The comparison or evaluation of a multitude of different indicators (as are included in our analysis) would be an overly complex task. An overall conclusion about energy sustainability and climate protection is more easily reached by focusing on one global figure describing the relevant development (comparable to the role attributed to GDP for assessing economic development).

Composite indices reduce complexity and provide useful instruments for policy monitoring, decision-making and communication with the public. Through the aggregation of single indicators to composite indices, information about specific details (e.g., sectoral developments), however, can be lost $[35,36]$. A composite index must therefore be regarded as a complement for the set of detailed indicators related to energy sustainability.

Special attention was devoted to including the social dimension of sustainable energy development in a more comprehensive way. There are several challenges that specifically arise when accounting for social aspects, including the "measurement problems" in the social sciences, i.e., the difficulty of reproducing theoretical constructs exactly and uniformly, such as "peace", "democracy" or "gender equality" because these constructs depend on the subjective perception of the individual, various characteristics are regarded as essential and they often depend on contexts [37]. No matter how precisely one formulates an indicator, it will never be able to exactly measure such vague and subjectively interpreted objects. The solution, then, as Meyer [38] argues, is not to create "better" indicators, but first and foremost to achieve "compromises that are commonly acceptable" on the level of theoretical constructs. As early as 2005 Littig and Griessler [39] identified shortcomings in the use of social sustainability indicators, including the absence of a clear theoretical concept of social sustainability, meaning abundance of diverging definitions of social sustainability ("social standards, institutional sustainability, democratic rights") as well as often unclear connections between the social, ecological and economic dimension and the lack of a proper integration of the three pillars of sustainability instead of separating them without transparent justification. The authors pointed out the need to integrate social sustainability indicators into policymaking in order to provide monitoring of relevant policies and to accompany them with evaluation and advice to ensure intended impacts of the political measures [39].

Following the considerations about which information would be useful to include in the indicator set, adjustments had to be made due to a lack of (1) time series data (e.g., for temporary contracts); (2) allocation of indicators to particular economic sectors (e.g., involuntary temporary employment, atypical working hours, continuing vocational training); and (3) internationally comparable data for all European countries (e.g., collective pay agreement, mobility data)—Despite the fact that gender matters regarding climate change and related policies and jobs, little 
attention is dedicated to these issues. Empirical research and data on gender inequalities are rare [40]. Further adaptations were required because a series of available indicators-collected for instance by the UN Statistics Division and Eurostat-are qualitative rather than quantitative. These indicators either depict attitudes (e.g., job satisfaction, work under pressure, job autonomy (possibility to influence content and order of tasks)) or survey qualitative characteristics about activities that are highly contingent and therefore impossible to interpret properly outside the specific context (such as time budgets, time use and satisfaction). For example, the United Nations Statistics Division provides time-use data, pointing out their importance: "They [time-use statistics] offer a unique tool for exploring a wide range of policy concerns including assessing quality of life or general well-being, analyzing division of labor between women and men, improving estimates of all forms of work (paid and unpaid) and estimating household production and its contribution to GDP" [41]. Statistics Austria's “Time use survey 2008/09” provides data about time distribution of different groups in society on different activities per day. The micro data was collected from around 8200 individuals aged 10 and over, via a daily diary for all activities lasting longer than 15 minutes, e.g., occupational activities, education, social contacts, gender specific division of housework, childcare, "real leisure time" in contrast to time for paid and unpaid work on the one hand and "spare time" used for sleeping, eating or personal care on the other [42].

They are not quantitative, as is generally the case with the economic or environmental indicators. Therefore, the subsequent reduction to a few key indicators, in addition to providing for the necessary focus on social issues, also inevitably generates gaps.

\section{Method}

The methodology for the calculation of the base sustainable energy index, which is based on a small number of indicators with comparably good data availability (see below), follows Davidsdottir et al. [43], Ibarran Vienniegra et al. [44] and Kettner et al. [43-45]. The composite index is either structured by sector or by dimension of sustainable development; in the former case, it is based on five sub-indices, one for each sector (transport, residential buildings, manufacturing, services, electricity and heat supply); in the latter case, it is based on three sub-indices:, one for the environmental dimension, one for the economic dimension and one for the social dimension. The sub-indices are calculated based on a distance to reference country approach according to the following equation:

$$
I B_{k, i, t}=\sum_{j=1}^{n} w_{j} \times\left(\frac{E_{k, i, j, t}}{E_{k=r, i j, t=0}}-1\right)
$$

where $I B_{k, i, t}$ gives the sub-index of sector $i$ in country $k$ in year $t, j$ is the energy indicator, $n$ is the number of indicators, $w_{j}$ is the weight for each indicator, $E_{k, i, j, t}$ is the value of the energy indicator in year $t$ and $r$ is the 
reference country. This means that each sub-index is the weighted sum of the change in the indicators compared to an assumed base year. The aggregate index is calculated as the weighted sum of the sub-indices. The indicators used to compute the index were normalized with the figures for Austria in 2010 to equal 100 to allow for a cross-country comparison.

Especially regarding the social dimension, relevant data are rarely available for multiple countries or as time series. Therefore, we chose to provide an extended composite index that includes additional (social) indicators but does not require the availability of data as a time series while performing a cross-country comparison based on the latest available year. While we could have also opted for a distance to reference country approach in calculating the extended composite index, we use the MinMax methodology described by the following equation

$$
I_{k, i}=\sum_{j=1}^{n} w_{j} \times\left(\frac{E_{k, i, j}-E_{\min , i, j}}{E_{\max , i, j}-E_{\min , i, j}}\right)
$$

with the aggregate index being again calculated as the weighted sum of the sub-indices. This approach is frequently used for calculating composite indices in the context of the measurement of well-being and sustainable development, for instance for the Human Development Index or the OECD Better Life Index. The values of the extended composite index will hence range between 0 (the worst performing country with respect to all indicators included) and 1 (the best performing country).

For the base composite indices, we selected 30 indicators (see Appendix B) that are shown in black in Table 1.14 indicators can be assigned to the environmental dimension, 13 to the economic dimension and 3 to the social dimension. In terms of sectoral disaggregation, 10 indicators pertain to the household sector, 7 to the transport sector, 4 each to the industry and service sector and 5 to electricity and heat supply.

The extended version of the index-accounting particularly for data gaps regarding the social dimension-was calculated including additional indicators that are only available for single years (in total, 42 indicators). These indicators are displayed in grey in Table 1. For this extended index, 13 indicators can be assigned to the residential sector, 12 to transport and 9 to electricity and heat supply; for industry and services again the same 4 indicators were used.

The indicators for the composite index were selected to provide information on the different levels of the energy system as illustrated in Figure $1 \mathrm{~B}$ and on all dimensions of sustainable energy development. While we stress the importance of energy services, we do not include proxies for measuring energy service demand in the composite index. The rationale for that is that the proxies (e.g., passenger kilometers (pkm) and tonne kilometers (tkm) for mobility as a proxy for the energy service mobility) cannot be interpreted in an unambiguous way (e.g., an improvement in energy efficiency will always be beneficial for sustainability, while this is not straightforward for an increase in the stock of appliances). 
Table 1. List of indicators included in the composite indices.

\begin{tabular}{|c|c|c|c|c|c|c|}
\hline $\begin{array}{l}\text { Dimension/ } \\
\text { Sector }\end{array}$ & Residential & Passenger $\mathrm{T}$. & Freight $\mathrm{T}$. & Industry & Services & Energy Supp. \\
\hline Economic & $\begin{array}{l}\text { Efficiency by use } \\
\text { category; } \\
\text { Share costs }\end{array}$ & $\begin{array}{l}\text { Efficiency } \\
\text { (pkm/PJ); } \\
\text { Share costs }\end{array}$ & $\begin{array}{l}\text { Efficiency } \\
\text { (tkm/PJ) }\end{array}$ & $\begin{array}{l}\text { Efficiency ( } € \\
\text { GVA/PJ FEC); } \\
\text { Share costs }\end{array}$ & $\begin{array}{l}\text { Efficiency ( } € \\
\text { GVA/PJ FEC); } \\
\text { Share costs }\end{array}$ & $\begin{array}{l}\text { Transformation } \\
\text { efficiency } \\
\text { Distribution } \\
\text { efficiency }\end{array}$ \\
\hline $\begin{array}{l}\text { Environ- } \\
\text { mental }\end{array}$ & $\begin{array}{l}\text { Share of RES; } \\
\mathrm{CO}_{2} \text { Efficiency }\end{array}$ & $\begin{array}{l}\text { Share of RES; } \\
\mathrm{CO}_{2} \text { Efficiency; } \\
\text { Share Rail }\end{array}$ & $\begin{array}{l}\text { Share of RES; } \\
\mathrm{CO}_{2} \text { Efficiency; } \\
\text { Share Rail }\end{array}$ & $\begin{array}{l}\text { Share of RES; } \\
\mathrm{CO}_{2} \text { Efficiency }\end{array}$ & $\begin{array}{l}\text { Share of RES; } \\
\mathrm{CO}_{2} \text { Efficiency }\end{array}$ & $\begin{array}{l}\text { Share of RES; } \\
\mathrm{CO}_{2} \text { Efficiency }\end{array}$ \\
\hline Social & $\begin{array}{l}\text { Affordability of } \\
\text { washing machine; } \\
\text { Affordability of } \\
\text { internet } \\
\text { connection; } \\
\text { Equipment rate of } \\
\text { dishwashers } \\
\text { Share of heating } \\
\text { costs in HH income }\end{array}$ & $\begin{array}{l}\text { Share of } \\
\text { alternative } \\
\text { drives in new } \\
\text { registrations; } \\
\text { Accessibility of } \\
\text { public } \\
\text { transport }\end{array}$ & & & & $\begin{array}{l}\text { Low wage earners; } \\
\text { Median hourly } \\
\text { earnings; } \\
\text { Collective pay } \\
\text { agreement; } \\
\text { Health and safety at } \\
\text { work; } \\
\text { Gender pay gap; } \\
\text { Gender employment } \\
\text { gap }\end{array}$ \\
\hline
\end{tabular}

RES = Renewable Energy Sources, GVA = Gross Value Added, FEC = Final Energy Consumption .

Figure 2A,B illustrates the way in which the indicators were aggregated to calculate the sectoral and dimensional sub-indices and subsequently the composite indices. The different compositions of the sub-indices thus determine the weight of the individual indicators in the calculation of the composite index and thus explain the disparity in the resulting total values. The lack of appropriate social indicators for manufacturing and services implies that in the aggregation by sector the social dimension is underrepresented. A better data availability of (quantitative) social indicators would improve the analysis. Equal weights were used for the calculation of the composite indices [46], i.e., at each stage of the composite index, the indicators/sub-indices are given the same weights (see Figure 2). Alternative weighting methods, each of which has its specific advantages and disadvantages [36], include e.g., statistical models such as principal components analysis, factor analysis or participatory methods that involve stakeholders. We opted for equal weights since this approach is used for many composite indices in the area of sustainable development (e.g., the SDG Index [1]) and can be easily implemented within the framework of this study. 
(A) Aggregation by sector and dimension

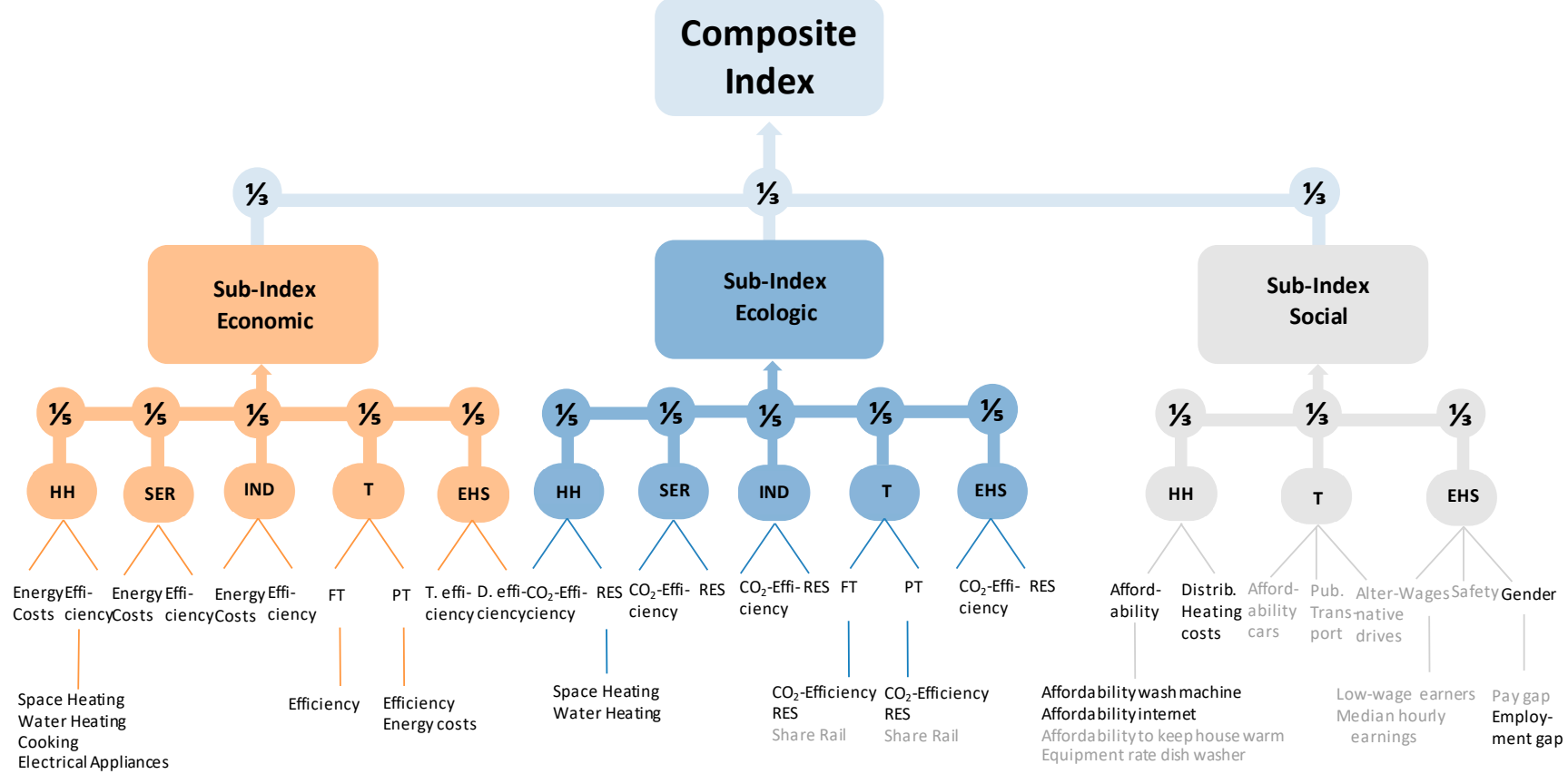

(B) Aggregation by dimension and sector

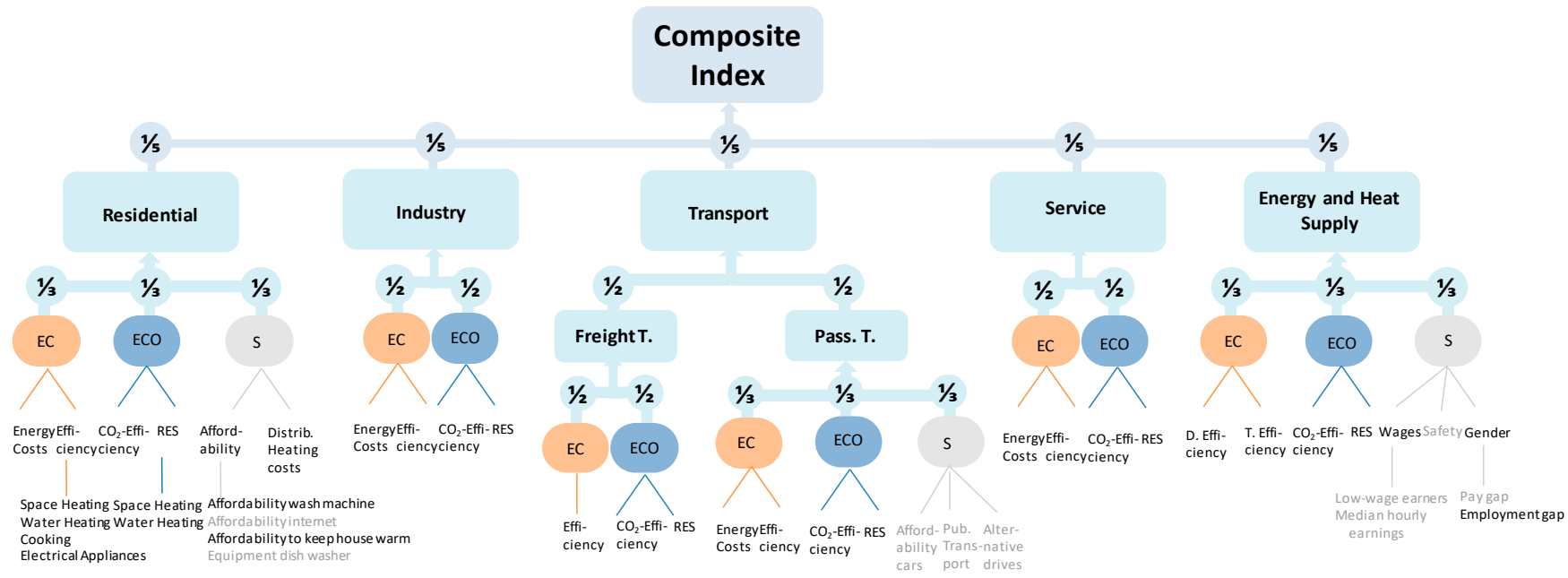

Figure 2. Aggregation structure of the composite indices.

\section{Data Sources}

Several databases were used to collect the indicators (see Appendix A1 for detailed information on the specification of indicators and data sources used):

- Odyssee: floor area of dwellings, passenger and freight transport performance as well as gross value added of the manufacturing and service sectors (proxies for energy services), and the related efficiency data, number of households, information on the different capital stocks and equipment rates, sectoral shares of renewable energy sources. The Odyssee database contains detailed information on energy consumption by end-use category and its drivers as well as energy 
efficiencies and $\mathrm{CO}_{2}$ related indicators. Underlying data are provided by national representatives, such as energy agencies or statistical organizations, from all EU countries as well as Norway, Switzerland and Serbia;

- The European Environment Agency's databases: newly registered vehicles;

- IEA: energy flows, i.e., final energy demand, transformation input and output by energy source (Energy Balances), energy prices and sectoral public energy expenditure;

- UNFCCC National Inventories: Sectoral GHG emissions;

- Eurostat: Household income and expenditures, other social indicators (Structure of Earnings Survey, the Labour Force Survey and the European Statistics on accidents at work).

In total, nine countries were selected for the detailed assessment of their sustainable energy development based on the indices described above. Apart from Austria, these comprise Denmark, France, Germany, Italy, the Netherlands, Poland, Spain and Sweden. We aimed at achieving a balanced mix of countries, i.e., small and large, northern and southern countries, as well as old and new EU Member States. Although the group of countries chosen represents a broad spectrum, the selection was eventually also determined by data availability. To be able to carry out cross-country comparisons we had to make sure that most of the indicators required for the indices were available.

For each country, various analyses were carried out: for the period 2005 to 2015 the sectoral and dimensional sub-indices as well as the composite indices were calculated to assess the trend and degree of sustainability in energy development. In addition, sensitivity analyses were performed; firstly, by using alternative weighting approaches for the aggregation of the indices, secondly, by calculating extended indices for the latest available year (2015), thus broadening the view on the social dimension of sustainable energy development. The dataset used for the analysis can be downloaded at http://clep.wifo.ac.at/ppts/Dataset Index.xlsx.

\section{DISCUSSION}

As described above, for the cross-country comparison (details on selected countries can be found in the Appendices) with the base index over time we chose the "distance to reference country" approach, normalizing the index with the figures for Austria in 2010 to equal 100. The development in the selected countries is measured against this benchmark, i.e., the focus is on how one country performs compared to others.

Figure 3 summarizes the development of the base index aggregated by dimension using equal weights for all indicators. Between 2005 and 2015 the performance measured with the composite index improved for all countries, albeit at different rates. While in 2005 two countries (Denmark, 
Sweden) ranked higher than Austria, due to different rates of change in 2015, only Denmark shows a higher value than Austria (with Sweden close behind). Although starting from a high level, Denmark managed to significantly improve its performance over time $(+17 \%)$. In both years France holds the 4th rank. Another group of countries (Germany, Netherlands, Italy, Spain) achieves values that are 8 to 10 points below Austria in both years. Of these countries, Italy shows the largest improvements over time, closing the gap with Germany and the Netherlands. Poland is clearly lagging behind, although it-together with Italy-shows one of the highest increases in the index over time (12\%). However, by and large the increase is not sufficient for Poland to catch up with the other EU countries. Another aspect worth noting is the temporal distribution of improvements. In some countries (most notably Denmark, France, Poland, Sweden) the advances in energy sustainability mainly occurred after 2010, while in others (Germany, Austria, Italy) the upward trend was stronger before 2010 .

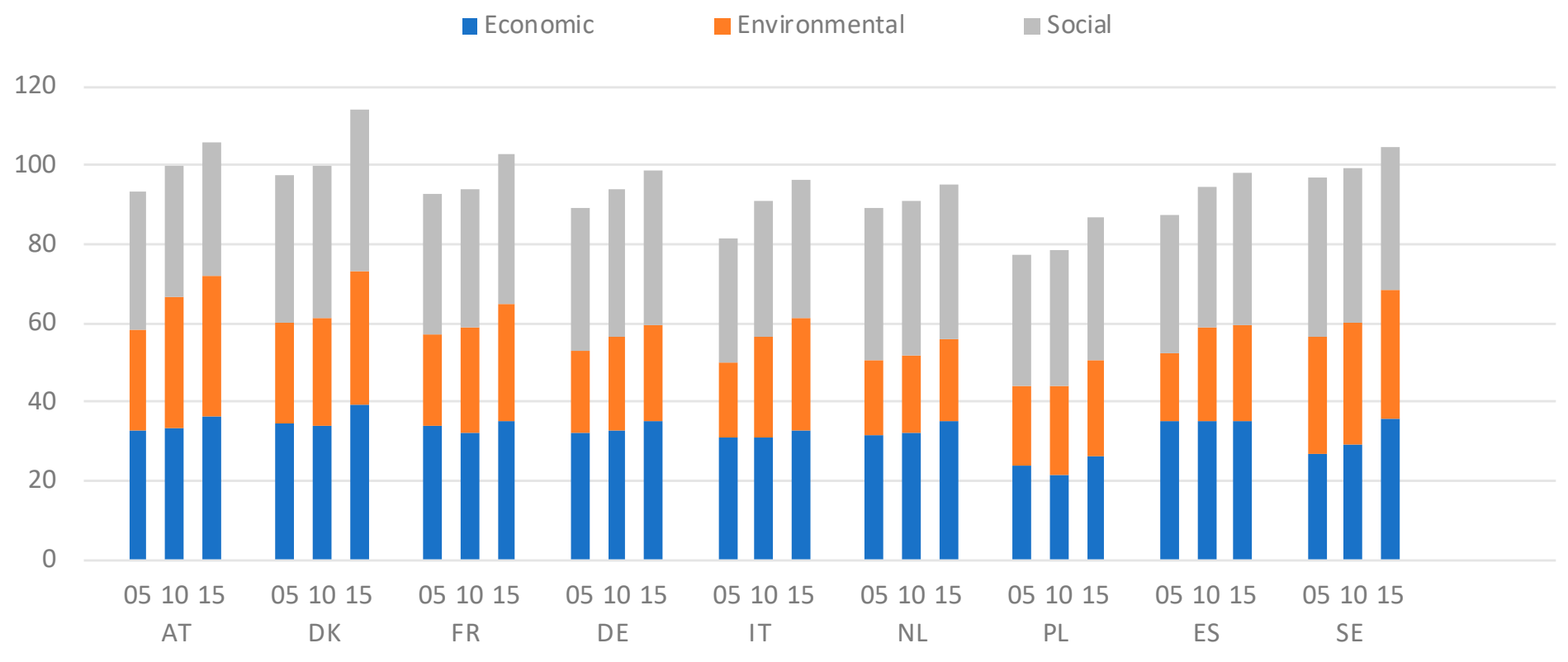

Figure 3. Development of base index aggregated by dimension, 2005, 2010 and 2015.

When taking a closer look at the developments in the three dimensions per country (see Figure C1 in Appendix C), it stands out that the strongest dynamic occurs in the environmental dimension, caused by rising shares of renewables and improved $\mathrm{CO}_{2}$ efficiency. Especially Austria, Italy, Denmark, France and Spain improved considerably, although the patterns of change differ among countries. While Austria, for instance, improved quite rapidly until 2010, after that the development stagnated. In contrast, the improvements in Denmark were more consistent over time. Italy and Spain achieved some catching up in the environmental dimension but have still not reached a high level of environmental sustainability in their energy systems. Sweden had the highest environmental sustainability level from the outset and still showed small but consistent improvements. 
On the other end of the scale, we find countries like Poland, the Netherlands and Spain with low to medium improvements and persistent low levels of environmental sustainability. These developments highlight on the one hand the role played by the availability of renewable resources and their utilization for individual countries (e.g., hydro-power in Sweden and Austria, and wind power in Denmark) as compared to the reliance on fossil resources found in Poland. On the other hand, they underline the importance of ambitious and stable environmental policies, as can be found in the Northern countries and that are characterized by broad societal and political acceptance, a long-term horizon and a rather high degree of integration of environmental or climate policy aspects in other policy areas.

Compared to the environmental dimension, little dynamism can be seen in the economic and social dimensions. In the former, this hints at a lack of significant improvements in energy efficiency-except for Sweden. Sweden definitely stands out with an increase that is twice as high as the one achieved by Denmark, which itself is above average. However, this can be interpreted as a catching up process, as Sweden starts out with a comparably low level of economic sustainability. Again, this can be attributed to the exemplary climate policy ambitions in Denmark and Sweden (the impact of Nordic climate policies has been studied by [47-51]). However, it also points out that, while the deployment of renewables has increased significantly over the decade analyzed, similar improvements regarding energy efficiency or energy saving have not taken place. In order to manage a fundamental energy transition and reach the decarbonization goal, efforts to improve energy efficiency will have to be increased drastically in all sectors.

With respect to the social dimension, improvements are generally modest. Similar developments can be observed in the energy sectors in Austria and Sweden despite differences in total employment. This is mainly due to the dominance of the gender employment gap in the calculation for the energy supply sector (see Table 1) - only one indicator, i.e., "Gender employment gap" is available for the composite index in the social dimension for the Electricity and Heat Supply sector. Four indicators were included in the extended version of the index, in addition to the Gender employment gap indicator: Low wage earners, Median hourly earnings, Fatal incidents and Gender pay gap). While the gender employment gap which measures the difference between the employment rates of men and women aged 20 to 64 for the overall economy in Austria has dropped by about 4.5 percentage points between 2005 and 2015, the gender employment gap in the energy supply sector fluctuated during this period and the value in 2015 is even higher than in 2005. The trend is even clearer when observing the reduction between 2000 and 2018 in the amount of 9.3\% [52]. Sweden is currently the only EU member state that has an employment rate above $80 \%$ (82.6\%); it also provided the highest employment rate for women in 2018 (80.4\%) and is listed as number three 
in the Global Gender Gap Index 2018 [53]. Sweden's score in the Global Gender Gap Index was 82.2\%. The Global Gender Gap Index, first introduced by the World Economic Forum in 2006, measures genderbased disparities using a scale from 0 (disparity) to 1 (parity) across four thematic dimensions-the sub-indexes Economic Participation and Opportunity, Educational Attainment, Health and Survival, and Political Empowerment-and provides country rankings that allow for comparisons tracing their progress over time. Despite imposing performance with one of the lowest gender employment gaps for the overall economy (4.3\% in 2018) [54] among the EU member states, the gender employment gap for the electricity supply sector increased significantly in 2015 as compared to 2005. Although Swedish women are well integrated into the labor market and the employment rates for women are almost as high as for men, the labor market is highly segregated, as women are overrepresented in the public sector and parttime employment is more frequent among women [54].

For the sectoral aggregation the overall development of the base index is depicted in Figure 4. The general pattern and positive development conform to the dimensional aggregation. Also, the group of the four best performing countries remains the same as for the aggregation by dimension (Austria, Denmark, France and Sweden). In this case, however, Sweden does not perform as well (rank 4); it shows more of a catching up development. The medium performers consist of three countries (Germany, Italy and Spain), while the Netherlands are closer to Poland, which brings up the rear.

In the sectoral perspective, improvements are generally more moderate. In the residential sector, very little improvement (in terms of efficiencies and share of renewables) can be seen. Interestingly, in this area Sweden shows nearly as low a level of sustainability as Poland. This reflects the large share of electricity in heating (nearly one third, consistently over the whole period) and the below-average improvements in the efficiency of space heating in general. This illustrates the sensitivity of results with respect to the choice of indicators on the one hand. On the other hand, the results reflect the sectoral disaggregation where the share of renewables in electricity generation is accounted for in the sector electricity and heat supply.

In transport, the dynamics are a little bit stronger-France in particular improved considerably. One contributing factor is the Bonus-Malus -Scheme that was introduced in 2008 and that-together with the scrap bonus for old diesel cars and carbon taxation-resulted in reduced energy demand from transport and lower average $\mathrm{CO}_{2}$ emissions of new vehicles [55,56]. In contrast, in Sweden and Germany the sub-index remains largely unchanged. The other countries achieved low to medium continuous improvements (starting from diverging levels of sustainability). The exceptions are Austria (with improvements only until 2010) and Denmark (improvements after 2010). 
Industry, in general, shows the strongest positive dynamics of all the sectors. However, the patterns of development differ among the countries. While Austria, the Netherlands and Germany are basically stagnating in terms of industrial sustainability, other countries have improved considerably. Denmark especially has managed to improve further, starting from an already high level of sustainability. This also holds true for Sweden, although from a lower starting level. Countries like Spain and Italy have made good progress in catching up.

The service sector in contrast remains practically unchanged with little to no improvement. The only exceptions are Austria with considerable efficiency improvements and Sweden with continuous but slightly slower progress.

The sub-index for energy supply is also largely stagnating. Only Denmark and Italy have achieved increases in sustainability. Poland and Spain managed some catching up but still remain under average. This leads to the conclusion that the efforts to increase the share of renewables in electricity generation and reduce the $\mathrm{CO}_{2}$ intensity of electricity and heat generation have not yet paid off. While Spain is characterized by fluctuations in emissions intensity, Poland shows no improvements at all in this respect. This is due to the particular circumstances in this country, which still relies heavily on its domestic coal resources (burned in largely outdated power stations) and regards climate policy as a mere compulsory exercise that has to be fulfilled for the EU [57]. However, for countries with high renewables shares from the outset (e.g., Austria or Sweden) significant improvements are difficult to achieve. In other countries there is also strong inertia in the energy market, especially due to a high share of nuclear energy (especially France with a mere increase in the share of renewables in electricity and heat generation of $3 \%$ ).

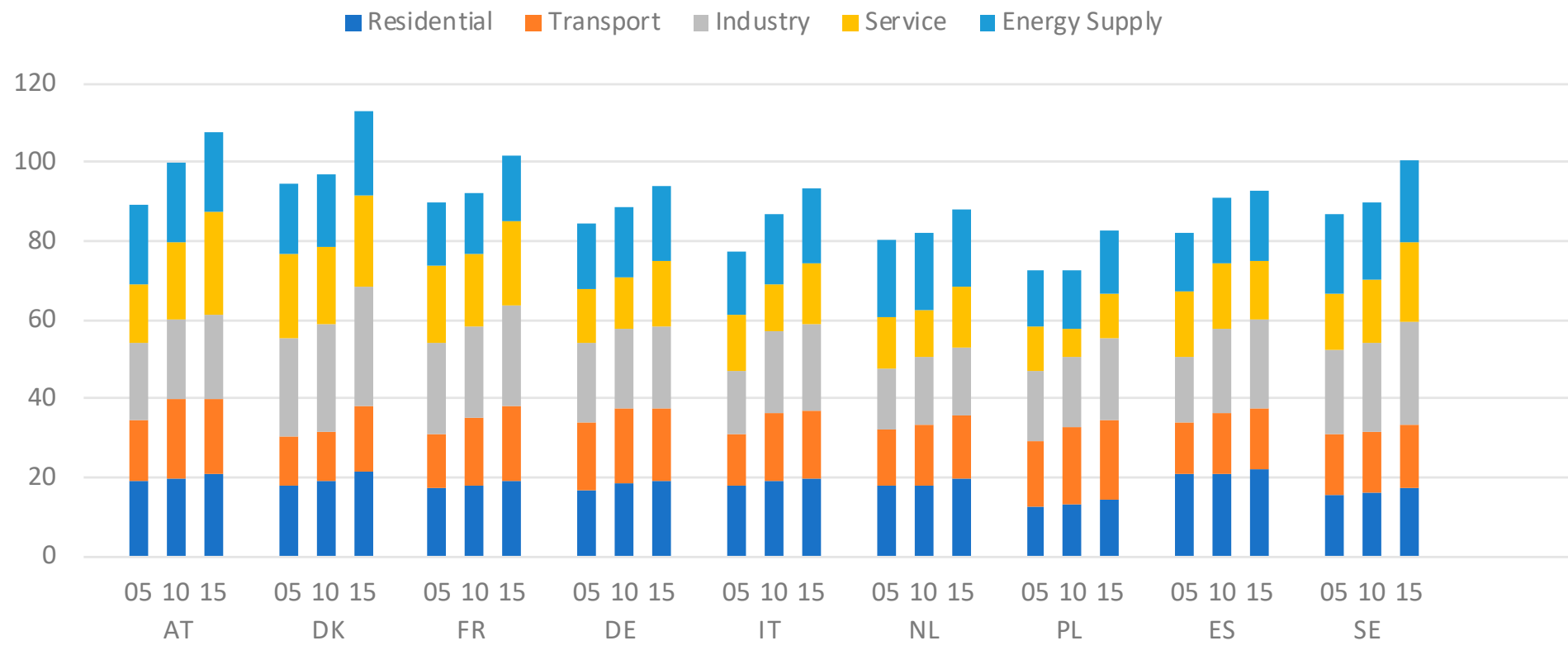

Figure 4. Development of the composite index aggregated by sector, 2005, 2010 and 2015. 


\section{Extending the Database for 2015}

For a more comprehensive set of indicators, including data that are not available for the whole period but are regarded as important for assessing sustainable energy development, an extended index was calculated for 2015 only. The additional indicators provide important information for the environmental and social dimensions, such as access to public transport, gender issues and working conditions in the energy supply sector. Again, the sub-indices for dimensions of sustainability and sectors were calculated and subsequently aggregated to compile the composite indices.

Figure 5 compares the results of the extended indices by dimension with the 2015 results using only the indicators from the base index.

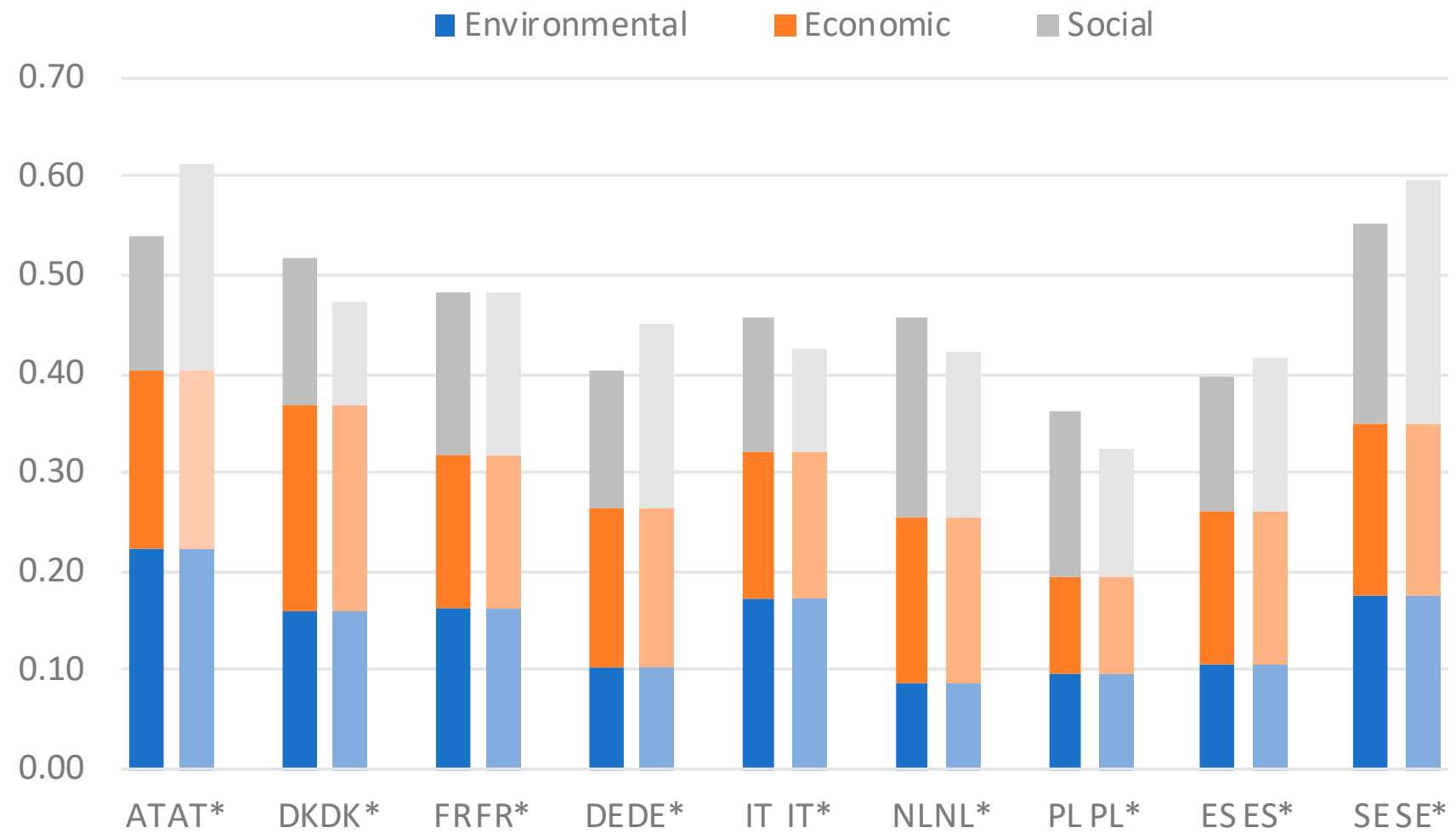

Figure 5. Comparison of the standard index and the extended composite index. * denotes the results of the MinMax methodology applied to the reduced indicator set of the base index.

The main differences can be summarized as follows: the greater number of social indicators reduces the spread in the index values among countries. It also leads to a decrease in the index values for Austria, Germany and Sweden, reflecting especially high differences in heating costs for different household groups in Austria and Sweden and a poor performance regarding the social indicators for transport for Austria and Germany. Austria also performs only poorly with respect to the newly included indicators for electricity and heat supply, most notably with respect to fatal incidents in the electricity sector and the gender pay gap. This results in a shift in the ranking of countries-Sweden and Austria 
change places (Austria drops from first to second rank), while Germany loses two positions. In other countries (Italy, Netherlands, Poland) the additional indicators increase the index values. While these three countries are improving in terms of their overall index score, the underlying factors differ substantially. The Netherlands shows relatively high scores with respect to all additional indicators, while Italy receives high scores for the transport-related indicators only, i.e., in terms of the share of alternative drives in newly registered cars, the affordability of cars, and access to public transport. In Poland, heating costs are most evenly distributed among different income groups and the lowest gender pay gap in electricity and heat supply can be observed. This illustrates that composite indices are a good means of describing aggregate developments, though at the cost of losing detailed information.

The first conclusion that can be drawn is that there are no significant changes in the overall ranking of countries or the composition of country groups if only a single year is analyzed (top performers Austria, Denmark, France and Sweden; medium performers Germany, Italy, Netherlands and Spain; tail light Poland) as compared to the results of the base index for 2015. However, the altered composition of the indicator set and the more comprehensive database deliver some changes at the sub-index level.

\section{CONCLUSIONS AND RECOMMENDATIONS}

For the research presented in this paper, we compiled a comprehensive indicator set for two of the 17 SDGs- "Affordable and clean energy" (SDG 7) and "Climate Action" (SDG 13) - and calculated composite indices for nine EU Member States to illustrate their progress toward sustainable energy development over a period of ten years. The advantage of composite indices is the aggregation of a multitude of data (by sector or dimension), which establishes a certain comparability of developments across countries and over time. At the same time, the aggregation of detailed information is the main shortcoming of the composite index because it is not the right tool with which to assess trade-offs and synergies among goals, sub-goals or indicators. The UN Agenda for Sustainable Development emphasizes the need for a universal and integrated approach in implementing the SDGs that accounts for synergies and tradeoffs. Still, despite the extensive amount of data collected, our research showed that in order to assess these interdependencies more detailed data would be required. Especially the achievement of goals in the social and environmental dimensions is often regarded as conflicting or even mutually exclusive. However, the impacts of policies on other dimensions depend on the specific policy design and the implementation of accompanying measures, e.g., the regressive effects of environmental taxation. The assessment of synergies and trade-offs in this context is restrained by the lack of quantitative information and indicators, particularly regarding the social dimension. 
The analysis of the composite indices for sustainable energy development shows that in general improvements regarding energy efficiency, emissions and deployment of renewables have been moderate between 2005 and 2015. This hints at the time required for restructuring to take place. Some countries showed above average positive developments. These are mainly countries that have a long tradition of ambitious environmental and climate policy-making and are also renowned for their social security systems (e.g., Denmark, Sweden). In contrast, Poland continues to focus its energy policy on coal. Deployment of renewables or emission mitigation is mainly regarded as a necessary exercise to fulfill requirements imposed by the EU. Positive developments, e.g., regarding the increase in renewables, seem to have happened despite, rather than because of, Polish policy-making. In addition, the country and sector comparisons show that each country is characterized by a very specific energy system (complemented by specific social structures) that determines the challenges that must be overcome. Thus, climate and energy policies need be customized to result in a successful strategy for the respective country.

These results, which are complemented by a more detailed policy analysis in selected countries, as described in the Appendices, highlight the importance of a credible political commitment to climate policy targets, the implementation of ambitious instruments and a stable policy framework ensuring investment certainty and predictability for consumers and firms [47,48]. Moreover, policies must be evaluated regularly with respect to their effectiveness and social impacts and must be adapted if necessary.

For evaluations to be feasible, programs have to be designed around quantifiable goals and the required databases have to be provided. Our approach can be regarded as one contribution within the broad field of measurement challenges. It also highlighted the need for new data. Trends such as digitalization, "crowd-work" and "proactive consumers" need to be considered regarding their influence on the quality of work and worklife balance by developing and using appropriate indicators. However, not all relevant aspects can be captured by quantitative indicators. While indicators are important tools for policy evaluation, non-quantifiable issues must also be included in policy evaluation to understand the relationships between policies and outcomes.

Given the defining features of the UN 2030 Sustainable Development Agenda-universality, i.e., that it applies to all countries and all goals, and the interconnectedness between goals and countries-further research is indispensable. So far, policy-making and policy analysis is predominantly fragmented and policies are guided by vested interests. To equilibrate various political targets, a stronger integration of policies is required such that the effects on the respective policy area are reciprocally taken into account in decision-making. It also requires a political "target function" for sustainable development similar to Sweden's intention to become a 
fossil-fuel free welfare state in order to solve conflicts of interest. Equally important is the availability of data sets, indicators and tools that provide adequate information to assess the progress towards achieving individual goals and sub-goals as defined in the SDGs as well as the synergies and trade-offs that arise in policy implementation.

\section{DATA AVAILABILITY}

The dataset used for the analysis can be downloaded at http://clep.wifo.ac.at/ppts/Dataset_Index.xlsx.

\section{AUTHOR CONTRIBUTIONS}

All authors jointly designed the study. CK made the calculations and contributed to the interpretation. The country comparisons were made by DK-S with input from all authors. All authors contributed to writing the paper.

\section{CONFLICTS OF INTEREST}

The authors declare that there is no conflict of interest.

\section{FUNDING AND ACKNOWLEDGMENTS}

This research was funded by the Climate and Energy Funds within the Austrian Climate Research Programme (ACRP). We would like to thank Katharina Köberl for excellent research assistance.

We are very grateful for the valuable comments from three anonymous reviewers. 


\section{APPENDICES}

Appendix A. Indicator specification and data sources.

\begin{tabular}{|c|c|c|c|}
\hline List of Indicators by Sector & Decription & Unit & Data Source \\
\hline \multicolumn{4}{|l|}{ Residential } \\
\hline \multicolumn{4}{|l|}{ Environmental } \\
\hline $\mathrm{CO}_{2}$ Efficiency & Final Energy Consumption Residential per unit $\mathrm{CO}_{2}$ & $\mathrm{PJ} / \mathrm{MT} \mathrm{CO}_{2}$ & UNFCCC, Odyssee-Database \\
\hline Share of Renewables in Final Energy Consumption Space Heating & Share of Renewables in Final Energy Consumption & $\%$ & Odyssee-Database \\
\hline Share of Renewables in Final Energy Consumption Water heating & Share of Renewables in Final Energy Consumption & $\%$ & Odyssee-Database \\
\hline \multicolumn{4}{|l|}{ Economic } \\
\hline Efficiency of final Energy Consumption Residential Cooking & Households per Final Energy Consumption Cooking & $\mathrm{HH} / \mathrm{PJ}$ & Odyssee-Database \\
\hline Efficiency of final Energy Consumption Residential Electrical Appliances & Households per Final Energy Consumption Electrical Appliances & $\mathrm{HH} / \mathrm{PJ}$ & Odyssee-Database \\
\hline Efficiency of final Energy Consumption Residential Space Heating & Floor Area per Final Energy Consumption Space heating & $\mathrm{m} 2 / \mathrm{PJ}$ & Odyssee-Database \\
\hline Efficiency of final Energy Consumption Residential Water Heating & Households per Final Energy Consumption Water heating & $\mathrm{HH} / \mathrm{PJ}$ & Odyssee-Database \\
\hline Share of housing energy expenditure in household expenditure & & $\%$ & Eurostat, COICOP \\
\hline \multicolumn{4}{|l|}{ Social } \\
\hline Persons who can afford a washing machine & Persons who can afford a washing machine & $\%$ & Odyssee-Database \\
\hline Population able to keep home adequately warm & Population able to keep home adequately warm & $\%$ & EU-Silc \\
\hline Persons who can afford internet connection for personal use at home & $\begin{array}{l}\text { Persons who can afford internet connection for personal use at } \\
\text { home }\end{array}$ & $\%$ & EU-Silc \\
\hline Equipment rate dishwasher & Equipment rate dishwasher & $\%$ & Odyssee-Database \\
\hline Distributon of heating costs & Quintile rate of energy expenditure & $\begin{array}{l}\text { Quintile } \\
\text { rate }\end{array}$ & Eurostat, Household budget survey \\
\hline
\end{tabular}




\section{Appendix A. Cont.}

\begin{tabular}{|c|c|c|c|}
\hline List of Indicators by Sector & Decription & Unit & Data Source \\
\hline \multicolumn{4}{|l|}{ Transport } \\
\hline \multicolumn{4}{|l|}{ Freight Transport } \\
\hline \multicolumn{4}{|l|}{ Environmental } \\
\hline $\mathrm{CO}_{2}$ Efficiency FT & Final Energy Consumption Freight Transport per unit $\mathrm{CO}_{2}$ & $\mathrm{PJ} / \mathrm{MT} \mathrm{CO}_{2}$ & UNFCCC, Odyssee-Database \\
\hline Share of Renewables in Final Energy Consumption FT & Share of Renewables in Final Energy Consumption & $\%$ & Odyssee-Database \\
\hline \multicolumn{4}{|l|}{ Economic } \\
\hline Efficiency_FT & Freight Transport per Final Energy Consumption & $\mathrm{tkm} / \mathrm{PJ}$ & Odyssee-Database \\
\hline \multicolumn{4}{|l|}{ Passenger Transport } \\
\hline \multicolumn{4}{|l|}{ Environmental } \\
\hline $\mathrm{CO}_{2}$ Efficiency PT & Final Energy Consumption Passenger Transport per unit $\mathrm{CO}_{2}$ & $\mathrm{PJ} / \mathrm{MT} \mathrm{CO}_{2}$ & UNFCCC, Odyssee-Database \\
\hline Share of Renewables in Final Energy Consumption PT & Share of Renewables in Final Energy Consumption & $\%$ & Odyssee-Database \\
\hline \multicolumn{4}{|l|}{ Economic } \\
\hline Energy cost share & Share of energy expenditure in household expenditure & in $\%$ & EU-Silc \\
\hline Efficiency_PT & Passenger Transport per Final Energy Consumption & $\mathrm{pkm} / \mathrm{PJ}$ & Odyssee-Database \\
\hline \multicolumn{4}{|l|}{ Social } \\
\hline Share of alternative Drives in newly registered cars & Share of alternative Drives in newly registered cars & $\%$ & $\begin{array}{l}\mathrm{EEA} \text {, Monitoring of } \mathrm{CO}_{2} \text { emissions } \\
\text { from passenger transport }\end{array}$ \\
\hline Affordability of cars & Persons who can afford a car & $\%$ & EU-Silc \\
\hline Access to public transport & $\begin{array}{l}\text { Distribution of population with very high level of difficulty in accessing public } \\
\text { transport }\end{array}$ & $\%$ & EU-Silc \\
\hline
\end{tabular}


Appendix A. Cont.

\begin{tabular}{|c|c|c|c|}
\hline List of Indicators by Sector & Decription & Unit & Data Source \\
\hline \multicolumn{4}{|l|}{ Industry } \\
\hline \multicolumn{4}{|l|}{ Environmental } \\
\hline $\mathrm{CO}_{2}$ Efficiency & Final Energy Consumption Industry per $\mathrm{CO}_{2}$ & $\mathrm{PJ} / \mathrm{MT} \mathrm{CO}_{2}$ & UNFCCC, Odyssee-Database \\
\hline Share of Renewables in FEC & Share of Renewables in Final Energy Consumption & $\%$ & Odyssee-Database \\
\hline \multicolumn{4}{|l|}{ Economic } \\
\hline Efficiency & Value Added per Final Energy Consumption & Mio. $€ \mathrm{GVA} / \mathrm{PJ}$ & Odyssee-Database \\
\hline Energy costs & Share of Energy costs in GVA & $\%$ of GVA & Odyssee-Database, IEA \\
\hline \multicolumn{4}{|l|}{ Service } \\
\hline \multicolumn{4}{|l|}{ Ecologic } \\
\hline $\mathrm{CO}_{2}$ Efficiency & Final Energy Consumption Service per unit $\mathrm{CO}_{2}$ & $\mathrm{PJ} / \mathrm{MT} \mathrm{CO}_{2}$ & UNFCCC, Odyssee-Database \\
\hline Share of Renewables in FEC & Share of Renewables in Final Energy Consumption & $\%$ & Odyssee-Database \\
\hline \multicolumn{4}{|l|}{ Economic } \\
\hline Efficiency & Value Added per Final Energy Consumption & Mio. $€ \mathrm{GVA} / \mathrm{PJ}$ & Odyssee-Database \\
\hline Energy costs & Share of Energy costs in GVA & $\%$ of GVA & Odyssee-Database, IEA energy prices \\
\hline \multicolumn{4}{|l|}{ Energy Supply } \\
\hline \multicolumn{4}{|l|}{ Environmental } \\
\hline $\mathrm{CO}_{2}$ Efficiency & Transformation output per unit $\mathrm{CO}_{2}$ & $\mathrm{MTCO}_{2} / \mathrm{PJ} \mathrm{TO}$ & UNFCCC, IEA Energy balances \\
\hline Share of Renewables & Share of Renewables in Transformation Input & $\%$ & IEA, Energy balances \\
\hline \multicolumn{4}{|l|}{ Economic } \\
\hline Distribution efficiency & Transformation output per Distribution losses & $\mathrm{PJ} / \mathrm{PJ}$ & IEA, Energy balances \\
\hline Transformation efficiency & Transformation output per Transformation losses & $\mathrm{PJ} / \mathrm{PJ}$ & IEA, Energy balances \\
\hline \multicolumn{4}{|l|}{ Social } \\
\hline Gender employment gap & Gap between number of men and number of women employed in the Energy Supply sector & Percentage points & Eurostat \\
\hline Fatal incidences & Incidence rate of fatal accidents at work for the Energy Supply sector & Incidence rate & Eurostat \\
\hline Gender pay gap & Gender pay gap for the Energy Supply sector & Percentage points & Eurostat \\
\hline Median hourly earnings & Median hourly earnings for all employees in the Energy Supply sector & $€$ & Eurostat \\
\hline Low-wage earners & Low-wage earners as a proportion of all employees in the Energy Supply sector & $\%$ & Eurostat \\
\hline
\end{tabular}


Appendix B. Country Rankings

Table B1. Country ranking by dimension.

\begin{tabular}{cccc}
\hline \multirow{2}{*}{ Countries } & \multicolumn{3}{c}{ Ranking } \\
\cline { 2 - 4 } & $\mathbf{2 0 0 5}$ & $\mathbf{2 0 1 0}$ & $\mathbf{2 0 1 5}$ \\
\hline AT & 3 & 2 & 2 \\
DK & 1 & 1 & 1 \\
FR & 4 & 5 & 4 \\
DE & 6 & 6 & 5 \\
IT & 8 & 7 & 7 \\
NL & 5 & 8 & 8 \\
PL & 9 & 9 & 9 \\
ES & 7 & 4 & 6 \\
SE & 2 & 3 & 3 \\
\hline
\end{tabular}

Table B2. Country ranking by sector.

\begin{tabular}{cccc}
\hline \multirow{2}{*}{ Countries } & \multicolumn{3}{c}{ Ranking } \\
\cline { 2 - 4 } & $\mathbf{2 0 0 5}$ & $\mathbf{2 0 1 0}$ & $\mathbf{2 0 1 5}$ \\
\hline AT & 3 & 1 & 2 \\
DK & 1 & 2 & 1 \\
FR & 2 & 3 & 3 \\
DE & 5 & 6 & 5 \\
IT & 8 & 7 & 6 \\
NL & 7 & 8 & 8 \\
PL & 9 & 9 & 9 \\
ES & 6 & 4 & 7 \\
SE & 4 & 5 & 4 \\
\hline
\end{tabular}

Table B3. Country ranking for extended index.

\begin{tabular}{lcc}
\hline \multirow{2}{*}{ Countries } & \multicolumn{2}{c}{ Ranking } \\
\cline { 2 - 3 } Extended Index & Extended Index with reduced indicator set \\
\hline AT & 2 & 1 \\
DK & 3 & 4 \\
FR & 4 & 3 \\
DE & 7 & 5 \\
IT & 6 & 6 \\
NL & 5 & 7 \\
PL & 9 & 9 \\
ES & 8 & 8 \\
SE & 1 & 2 \\
\hline
\end{tabular}


Appendix C. Country-Specific Development of the Composite Index Aggregated by Dimension

(a) Austria

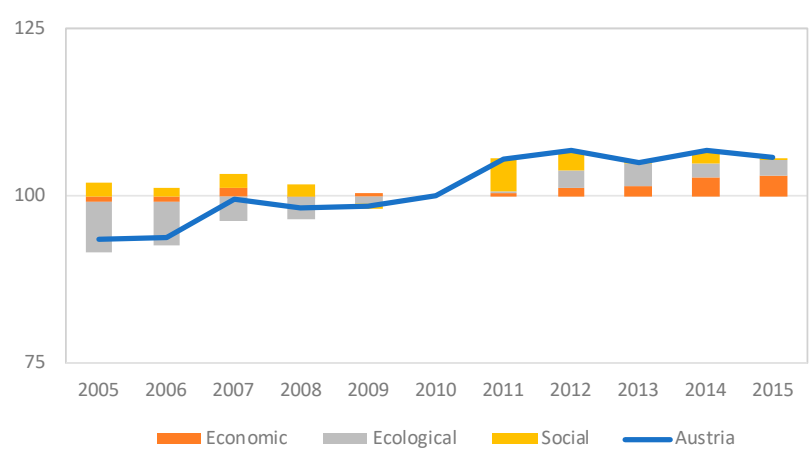

(c) Denmark

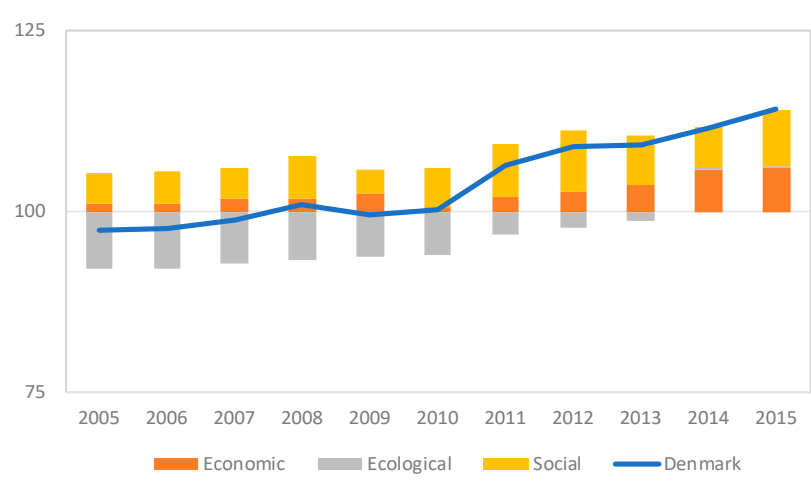

(e) France

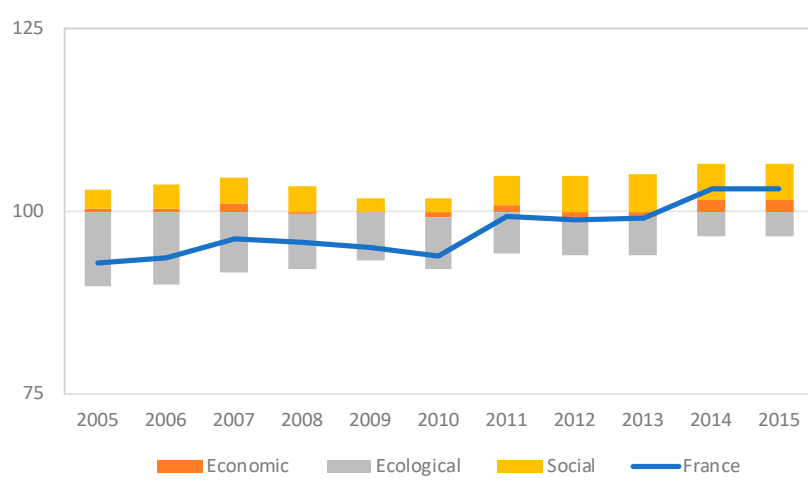

(g) Germany

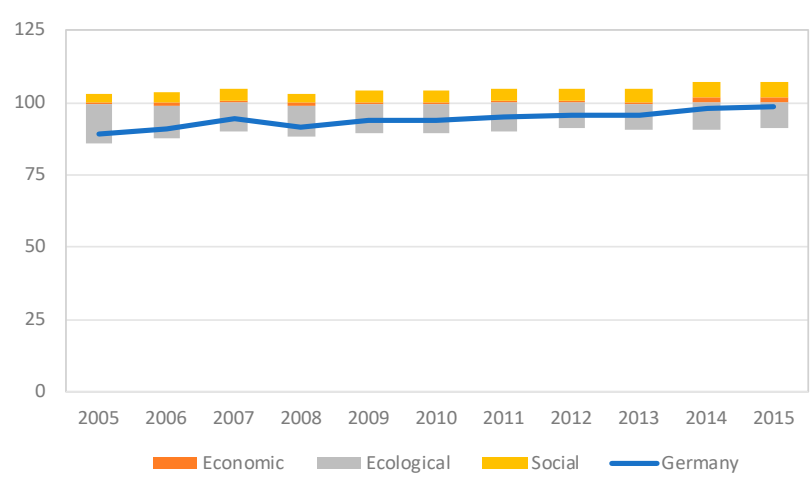

(b) Netherlands

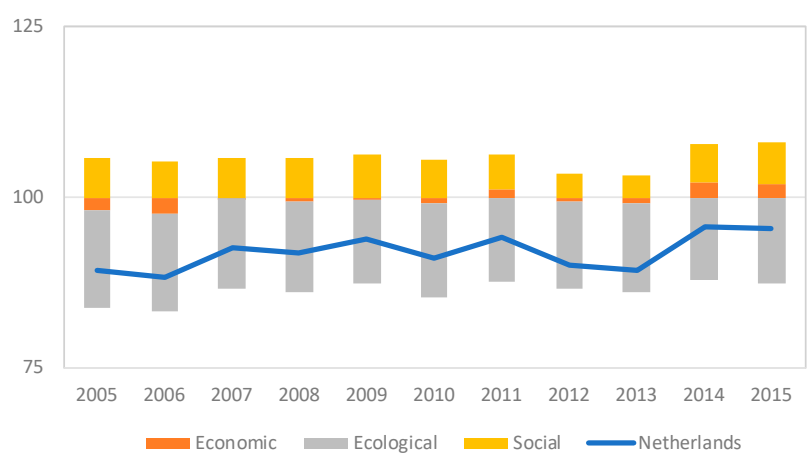

(d) Poland

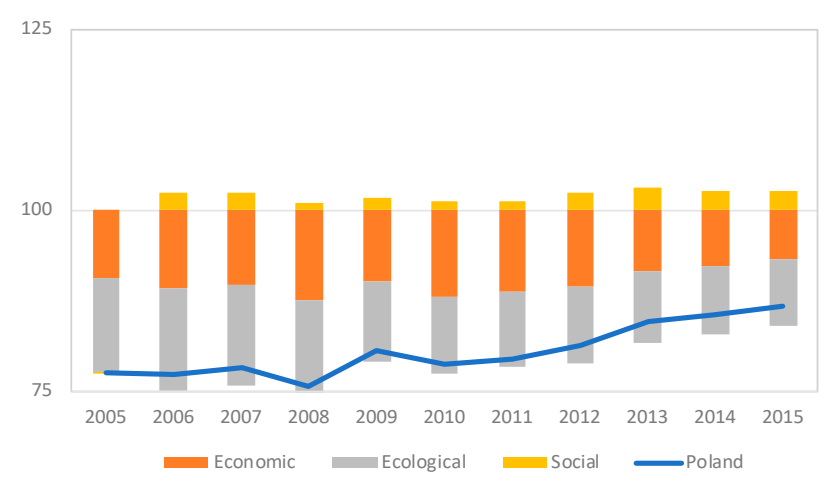

(f) Spain

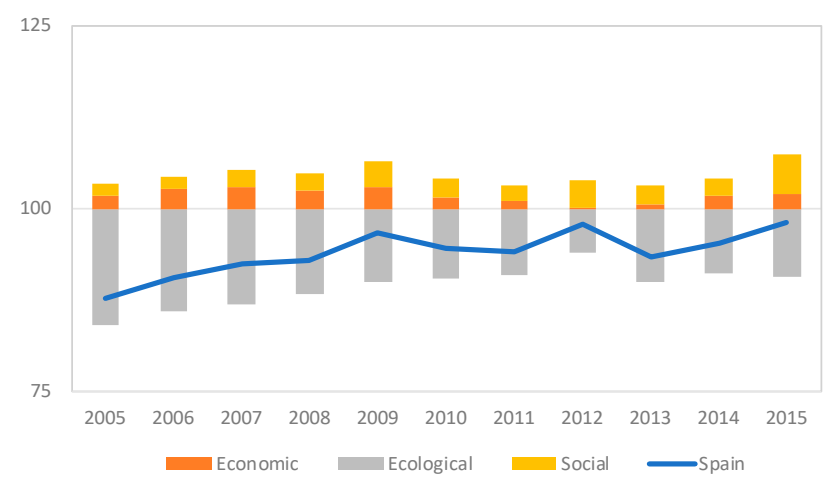

(h) Sweden

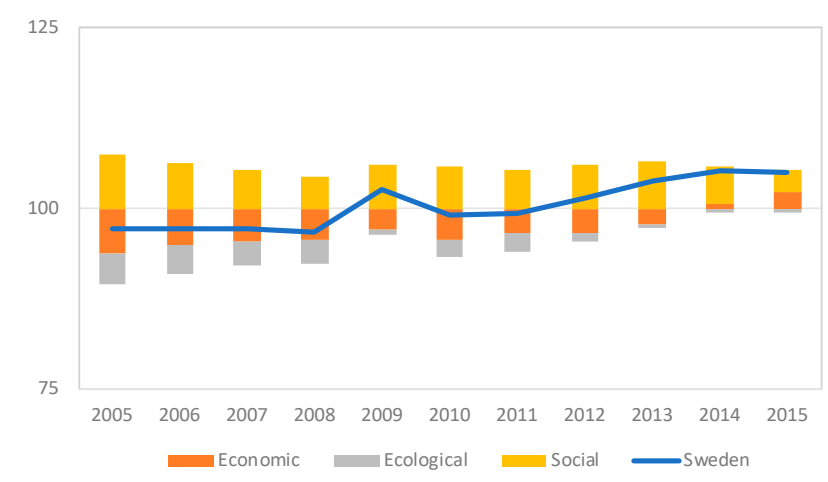

Figure C1. Development of composite index aggregated by dimension 2005-2015. 
(i) Italy

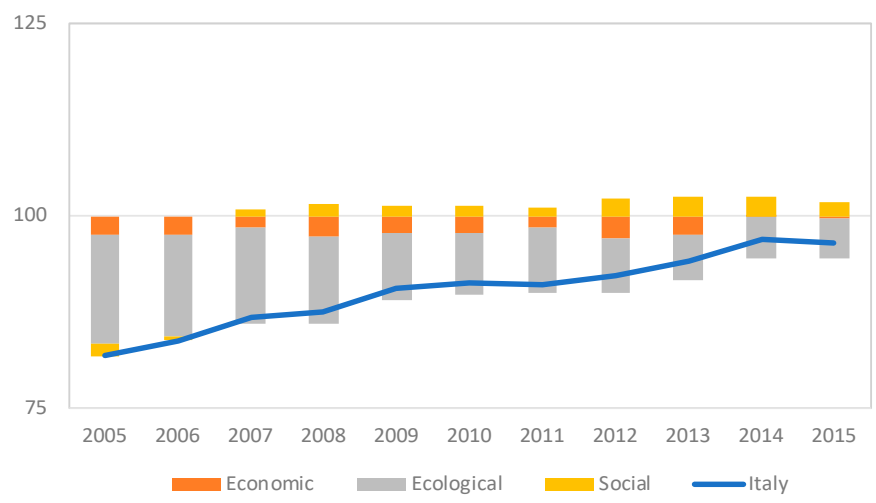

Figure C1. Cont.

\section{Appendix D. Policy Background on Selected Countries}

\section{Denmark}

Denmark has a long tradition of environmental and climate policies, complementing international agreements with ambitious national targets and corresponding policy instruments. One major example of this is the early introduction of a $\mathrm{CO}_{2}$ tax (1992), which inter alia included differentiated tax rates for industry depending on the energy intensity of the processes applied and which led to energy monitoring, management and energy-saving investments using a kind of "forced volunteerism". The approach consists of both a voluntary agreement and an Executive Order. If an obligated party refuses to accept a voluntary agreement or to fail to follow the agreed regulations, then the Danish Energy Agency will issue an injunction forcing the obligated party to follow the requirements in an Executive Order, which is largely based on the voluntary agreement. If the obligated party refuses to follow the injunction, then the Danish Energy Agency may issue a fine [58,59]. Not least, the $\mathrm{CO}_{2}$ tax scheme coupled with the energy efficiency agreements resulted in a significant reduction of final energy demand in industry (-16\% between 1990 and 2017). The carbon taxation scheme was complemented by other measures like the Energy Efficiency Obligation (EEO) Scheme for energy suppliers, which initially focused on raising awareness of energy savings and later (from 2006 onwards) encompassed the implementation of measures for end users (especially in the building, appliances and industry sectors). Energy Efficiency obligations are described as an obligation by a party (usually final energy suppliers or distribution network operators) to deliver a defined amount of energy savings within a certain period of time. The scheme is based on a voluntary agreement, and currently three gas companies, six oil companies, 74 electricity companies and 417 district heating companies are participating [58]. In most years overachievements of the aspired energy savings were reached. Only in 2013 to 2015 was this not the case, as the targets set in the EEO were raised significantly and the low-cost energy-saving measures had already been implemented or were 
no longer applicable due to stricter additionality criteria. Therefore, in 2016 the energy- saving targets were again revised downward (to 10.1 $\mathrm{PJ} /$ year, corresponding to about $2.5 \%$ of final energy demand). Despite its success, the scheme will be discontinued after 2020 and replaced by other approaches.

As another pillar, energy policy focused on the transformation of an electricity system based on fossil fuels into one with a high share of renewables, which was driven by ambitious investments (mainly in wind energy),) but also emphasized the importance of RD\&I. Denmark is among the global leaders in the use of energy-efficient technologies, including combined heat and power (CHP), which provides half the electricity and two-thirds the heat needed.

Denmark's energy intensity and carbon intensity are among the lowest of all IEA member countries [60]. Between 2005 and 2015 Denmark managed to reduce primary energy consumption by $14 \%$ and final energy consumption by $10 \%$ (Eurostat). At the same time, the share of renewable energy in gross final energy consumption nearly doubled from $16 \%$ to $31 \%$. Greenhouse gas emissions declined by 25\%. All sectors except transport reduced their emissions.

According to IEA (2017) [60] the Danish energy policy is inter alia characterized by:

- broad and sustained political support for a low-carbon transition;

- a holistic approach to energy planning, paying great attention to interactions and synergies among different sectors and various policies and regulatory instruments; and

- stakeholder engagement and informed decision-making based on socio-economic analysis and projections.

These elements and the reliance on broad energy agreements have contributed to achieving a high degree of predictability and continuity in energy policy, which in turn has increased investment security for renewable energy or energy efficiency projects. Danish energy policy is defined in Energy Agreements that are revised every five years. The latest was passed in 2018 and includes the pathway to reaching the 2030 climate policy targets. The Energy Agreements include specific sub-targets (e.g., for the development of certain renewables, energy efficiency, etc.) together with particular initiatives, the respective time paths and funding volumes per year. This facilitates the monitoring and evaluation of outcomes and of the effectiveness of policies implemented [61]. In addition, based on the Climate Law passed in 2014, a scientific council on climate change was instated, an energy policy report is submitted annually to parliament and new national climate targets are established each year. The overall objective of the law was to establish a stable framework and give directions towards the 2050 goal of a low carbon society (Danish Energy Agency). A national greenhouse gas reduction target of $40 \%$ by 2020 compared to 1990 levels was also approved in Parliament in 2014. 
Denmark has set itself national targets that go beyond the EU targets for 2020. Furthermore, it has an ambitious strategy for long-term (2050) emission reduction, renewables and energy efficiency. A broad majority (political as well as societal) supports the 2050 target of an energy system with $100 \%$ renewable energy without any reliance on fossil fuels. This political stability, ambitiousness of targets and early implementation of policy instruments have led to significant emission reductions on the one hand and technological leadership on the other. For the future, decarbonization path challenges remain to be tackled [62], particularly concerning further improvements in energy efficiency, decarbonizing transport and actually reaching the $100 \%$ renewables in the energy system, including ways to adjust for the variability of wind energy generation and to add flexibility to the heat and power system.

\section{Sweden}

Like Denmark, Sweden has a long tradition of ambitious environmental policy-making and early implementation of a carbon tax, which has been the key climate policy instrument since 1991. The $\mathrm{CO}_{2}$ tax is the highest worldwide (currently $120 € / \mathrm{t} \mathrm{CO}_{2} \mathrm{e}$ ) and applies to transport, buildings (heating), industry and agriculture.

The carbon tax combined with other instruments and measures has helped to reduce $\mathrm{CO}_{2}$ emissions by approximately $24 \%$ between 1990 and 2015 [63] and also has decreased energy consumption slightly. The taxes have further been supplemented with an electricity certificates system for increasing the share of renewables, technology procurement, public information campaigns, a differentiated annual vehicle tax and investment grants [64] (especially the massive expansion of district heating and the accompanying shifts to biomass as an energy source and to electrification in heating) Sweden has the lowest emission intensity in the EU (both as emissions per unit of GDP and per unit of energy use). Analyses [65-68] show that the carbon tax has been effective in reducing carbon emissions, especially in those sectors that have to pay the full tax rate. Although energy-intensive industries have previously been granted generous tax exemptions and are now exempt from the carbon tax because they participate in the EU ETS, $\mathrm{CO}_{2}$ emissions from manufacturing have been reduced by one third since 1990 and emission intensity has significantly improved.

In general, Swedish climate policy can be regarded as ambitious and the national "integrated climate and energy policy" (2009) went beyond the objectives determined by EU policy. However, the previously planned phase-out of nuclear power was abrogated and the option to replace the reactors at the existing sites was ensured. Nuclear energy plays a significant role in the Swedish energy system because it contributes between 40 and 50\% of electricity generation. The 2016 Energy Agreement endorsed the regulation that no forced phase out of the existing nuclear capacity is scheduled [69]. However, Sweden aims for a $100 \%$ share of 
renewables in electricity generation by 2040 . The other half comes mainly from hydro power with an increasing share of wind power in recent years (the share of wind power in total electricity generation increased from $1 \%$ (2005) to $16 \%$ (2015)). Thus, fossil fuels do not play a role in the Swedish electricity sector.

For the long term, Sweden defined four priority targets in the new climate policy framework (2017) and the Climate Act of 2018:

- zero net greenhouse gas emissions by 2045 (and negative emissions thereafter),

- by 2030 emissions from domestic transport will be reduced by at least $70 \%$ (relative to 2010),

- by 2030 emissions from the sectors covered by the EU Effort Sharing Regulation will be reduced by at least $63 \%$ (relative to 1990 ); and by $75 \%$ by 2040 .

In addition, a Climate Council was installed. The emphasis of the country's climate strategy lies on the use of economic instruments, supplemented with targeted instruments-for example, support for the development and market introduction of technologies and the elimination of barriers to energy efficiency.

In a manner similar to Denmark, Sweden has aimed at aligning its R\&D policies with its energy and climate objectives. Research and innovation are strongly focused on the country's strengths in bio-fuels and smart grids [70], and are oriented towards market deployment. There is also a strong involvement of the private sector, both in terms of financing R\&D and in formulating strategic plans. Thus, climate-relevant research has received stable public support.

The Swedish Government has adopted the objective to make Sweden one of the world's first fossil-free welfare states. The challenge will mainly lie in achieving the further improvements required, starting from the already high level of energy sustainability.

\section{France}

In recent years, France has made good progress in improving its energy efficiency, carbon intensity and decoupling of carbon emissions from economic activity. One key aspect of France's energy system, however, is the large share of nuclear power-on average 76\% (2005-2015) of gross electricity generation (Eurostat). Nuclear energy can contribute to reducing greenhouse gas emissions but its compatibility with sustainable development is contested, notably because of problems concerning safety, weapons proliferation, waste handling and high costs [71]. The share of renewables (mainly hydropower) in electricity generation increased in this period, from $10.6 \%$ to $16.6 \%$. Electricity generation by coal has been drastically reduced and will be phased out, as is also the case for oil-fired power plants [56]. Between 2005 and 2015, $\mathrm{CO}_{2}$ emissions decreased by $20 \%$. There have been emission reductions in all sectors of the economy. 
The smallest decrease took place in the transport sector, which is the largest source of $\mathrm{CO}_{2}$ emissions (29\%).

Lately, France has increased its efforts towards achieving decarbonization with the development of an integrated energy and climate policy framework for 2030 and has implemented new policies like the carbon tax [72], the Bonus-Malus scheme for vehicles and the Energy Transition tax credit. In particular, the Bonus-Malus scheme for vehicle registration has proven effective in reducing average emissions from passenger cars [55]. The scheme has been modified various times since its introduction in 2008; the rates have been adapted to technological changes and the incentive for purchasing low emission vehicles has been stepped up. In the scheme, bonus payments are granted for electric vehicles (prior to 2017 also for low emission vehicles), which are financed by the revenues from the fees on emission-intensive vehicles [55]. The scheme has been effective, as average vehicle emissions have decreased by $25 \%$ since implementation.

The basis for the French national climate and energy policy is the Act on Energy Transition for Green Growth ("La loi relative à la Transition Énergétique pour la Croissance Verte”, LTECV, 2015). The Act obliges energy suppliers and consumers to contribute to reducing GHG emissions while safeguarding economic growth. The national targets foresee in particular:

- a $40 \%$ reduction in GHG emissions by 2030 and a $75 \%$ reduction by 2050 (“factor four") from 1990 levels;

- a cut in final energy consumption of $20 \%$ by 2030 and $50 \%$ by 2050 compared to 2012 and a $2.5 \%$ annual reduction rate for final energy intensity until 2030.

Two strategic plans were developed for the implementation of the longterm targets and the provision off investment security: the Multiannual Energy Programme 2014-2020 ("Programmation Pluriannuelle de l'Énergie” 2014-2020, PPE) and the national low-carbon strategy ("Stratégie Nationale bas-Carbone", SNBC). The SNBC contains five-year carbon budgets that reflect the targets of the LTECV and specifies policies with which to achieve them. The energy programming covers energy production, energy efficiency, security of supply, and the supply/demand balance for all energy sources.

Sectoral strategies have been adopted for the "Energy Transition: a low carbon mobility strategy" (2016) with measures that focus on the further deployment of electric vehicles with 7 million EV charging points planned for 2030. In the buildings sector, the object is to renovate 500,000 dwellings per year. The renovation of low-income households is targeted specifically under the Better Living Programme. Building codes have been strengthened with the new thermal renovation regulations of 2012. One key aspect is the accelerated deployment of renewables, whose share in electricity supply is projected to rise to $40 \%$ by 2030 [73] while at the same 
time reducing nuclear capacity. In order to achieve this target, it will be necessary to double the growth rates for renewables as compared to the past ten years. Therefore, especially non-economic barriers (like administrative procedures, lack of societal acceptance, grid integration) will have to be overcome [56].

\section{Poland}

Defining itself as a "coal country", Poland is generally not supportive of climate policy targets and seeks to avoid energy system transformations towards more sustainable or decarbonized structures. Poland was the only EU member state who vetoed the Low-Carbon 2050 roadmap and the Energy 2050 Roadmap. Although some progress is apparent in our indicator set and is also attested e.g., by the IEA review [74], Poland's performance in terms of energy sustainability and compliance with climate policy targets remains under average (compared to the EU average as well as compared to other Central and Eastern European countries).

The energy system continues to rely heavily on coal, which provided around $50 \%$ of primary energy supply and $80 \%$ of electricity production in 2015 (Eurostat). The further use of the domestic resources of hard coal and lignite (as the cheapest form of energy generation) are a central element of Poland's energy policy and is also seen as a prerequisite for ensuring security of supply. The combustion of coal is therefore the predominant source of GHG emissions. In addition, the direct and indirect employment related to coal mining is regarded as being of high importance in terms of its social and regional impact. It has to be stated, however, that employment in coal mining decreased by 78\% between 1989 and 2015, with further declines thereafter. At the end of 2015 around 90,000 people were directly employed in hard coal mining; by the end of 2016 this number decreased to $84,600[75,76]$ representing $0.5 \%$ of total employment. Furthermore, despite public subsidies, the sector is suffering huge losses [77].

Nearly two thirds of Poland's coal-fired power plants are more than 30 years old and are highly inefficient. Also, the district heating system, which is one of the largest in Europe, is in need of reinvestments. Given these huge reinvestment requirements, the energy sector is at a crucial point and the strategic decisions with respect to technological choices will determine the country's energy use and emissions for the coming decades. Similarly, the building stock is highly inefficient and in need of comprehensive refurbishment. Change is also needed in the heating systems (in the part of dwellings not covered by district heating) that largely depend on coal.

So far, to preserve the coal-based energy system, significant support has been granted. On the one hand, Poland is one of eight EU member states that are allowed to allocate free ETS allowances to existing fossil power plants until 2019. Although the intention was to help finance the retrofitting and upgrading of infrastructure and the diversification of the 
energy mix, this measure supports coal-fired power plants. The main support measure benefitting coal-fired electricity generation was the support for biomass, which is largely co-fired in coal power plants and in this case is regarded as a renewable energy source although it is not used independently from its fossil complement [57].

In contrast to the political focus on coal, the data show that Poland has made progress regarding the use of renewable energy sources, with the share in gross final energy consumption increasing from 6.9\% (2005) to $11.7 \%$ in 2015; in electricity generation the share of renewables rose from $2.7 \%$ (2005) to $13.4 \%$ (2015). Particularly, wind energy has grown significantly in recent years (from $83 \mathrm{MW}$ to $5100 \mathrm{MW}$ installed capacity between 2005 and 2015), putting Poland at 7th place in the EU regarding installed wind power capacity. However, about half of the increase in renewable generation stems from biomass co-firing in coal power plants.

With several changes in the strategies and legislation concerning renewables, future energy development in Poland is uncertain. Apart from the continuous big role attributed to coal in the medium to long term in the country's energy strategy ( $60 \%$ in $2030 ; 50 \%$ in 2050) complemented by the plans to invest in new coal-fired power plants as well as in two nuclear power plants, Poland has significantly changed its renewable electricity support scheme. Since 2016, auctions (separate for "technology baskets") have been carried out, replacing the former scheme based on renewables quotas and green certificates [57]. In this context, the biggest budget is dedicated to so-called "stable sources", i.e., mainly biomass cofiring. Furthermore, the "Wind Farm Act" of 2016 considerably restricted further deployment of wind power. The Act prohibited building wind turbines within 1.5 to $2 \mathrm{~km}$ of buildings or natural conservation areas, thus ruling out $99 \%$ of the land. Also, the real estate tax on windmills was raised substantially and stricter control and permitting requirements were passed.

From the current point of view, the transformations in the Polish energy system observed over the past years will slow down as the current policy framework further decreases profitability and investment security for renewables. It seems as though renewables development is not supported as a means of reaching climate policy goals, but only to fulfill requirements imposed on Poland by the EU. Poland seems to be dismissing decarbonization and following its own path, as the energy minister declared in 2016 [78].

\section{REFERENCES}

1. Bertelsmann Stiftung and Sustainable Development Solutions Network (SDSN). SDG Index \& Dashboards A Global Report. Gütersloh (Germany): SDSN; 2016.

2. General Assembly of the UN. Transforming our World: The 2030 Agenda for Sustainable Development. New York (US): UN General Assembly; 2015. Report No.: Seventieth session Agenda items 15 and 116. Available from: 
https://sustainabledevelopment.un.org/post2015/transformingourworld.

Accessed 2019 Sep 23.

3. Allen M, Babiker M, Chen Y, Coninck H. Summary for Policymakers. In: Global Warming of $1.5^{\circ} \mathrm{C}$. Geneva (Switzerland): IPCC; 2018.

4. The World in 2050 (TWI2050). Transformations to Achieve the Sustainable Development Goals. Laxenburg (Austria): TWI2050; 2018. Available from: http://twi2050.org. Accessed 2019 Sep 23.

5. Littig B, Griessler E. Soziale Nachhaltigkeit. Informationen zur Umweltpolitik, Bd 160. Vienna (Austria): Bundeskammer für Arbeiter und Angestellte; 2004. German.

6. Cullen JM, Allwood JM. The efficient use of energy: Tracing the global flow of energy from fuel to service. Energy Policy. 2010;38:75-81.

7. Gouveia JP. Projections of energy services demand for residential buildings: Insights from a bottom-up methodology. Energy. 2012;47:430-42. doi: 10.1016/j.energy.2012.09.042

8. Sovacool BK. Security of energy services and uses within urban households. Curr Opin Environ Sustain. 2011;3:218-24. doi: 10.1016/j.cosust.2011.06.004

9. Sovacool BK. Conceptualizing urban household energy use: Climbing the “Energy Services Ladder”. Energy Policy. 2011;39:1659-68. doi: 10.1016/j.enpol.2010.12.041

10. Haas R, Nakicenovic N, Ajanovic A, Faber T, Kranzl L, Müller A, et al. Towards sustainability of energy systems: A primer on how to apply the concept of energy services to identify necessary trends and policies. Energy Policy. 2008;36:4012-21.

11. Köppl A, Kettner C, Kletzan-Slamanig D, Schleicher S, Damm A, Steininger K, et al. Energy Transition in Austria: Designing Mitigation Wedges. Energy Environ. 2014;25:281-304. doi: 10.1260/0958-305X.25.2.281

12. Ma L, Allwood JM, Cullen JM, Li Z. The use of energy in China: Tracing the flow of energy from primary source to demand drivers. Energy. 2012;40:174-88.

13. Janoušková S, Hák T, Moldan B. Global SDGs Assessments: Helping or Confusing Indicators? Sustainability. 2018;10:1540. doi: 10.3390/su10051540

14. Allen C, Metternicht G, Wiedmann T. Initial progress in implementing the Sustainable Development Goals (SDGs): a review of evidence from countries. Sustain Sci. 2018;13:1453-67. doi: 10.1007/s11625-018-0572-3

15. Schmidt-Traub G, Kroll C, Teksoz K, Durand-Delacre D, Sachs JD. National baselines for the Sustainable Development Goals assessed in the SDG Index and Dashboards. Nat Geosci. 2017;10:547-55. doi: 10.1038/ngeo2985

16. Simon D, Arfvidsson H, Anand G, Bazaz A, Fenna G, Foster K, et al. Developing and testing the Urban Sustainable Development Goal's targets and indicators-a five-city study. Environ Urban. 2016;28:49-63. doi: 10.1177/0956247815619865

17. Kawakubo S, Murakami S, Ikaga T, Asami Y. Sustainability assessment of cities: SDGs and GHG emissions. Build Res Inf. 2018;46:528-39. doi: 10.1080/09613218.2017.1356120

18. Allen C, Nejdawi R, El-Baba J, Hamati K, Metternicht G, Wiedmann $\mathrm{T}$. Indicator-based assessments of progress towards the sustainable development goals (SDGs): a case study from the Arab region. Sustain Sci. 2017;12(6):975-89. doi: 10.1007/s11625-017-0437-1 
19. Valensisi G, Karingi S. From global goals to regional strategies: towards an African approach to SDGs. Afr Geogr Rev. 2017;36:45-60. doi: 10.1080/19376812.2016.1185738

20. Campbell BM, Hansen J, Rioux J, Stirling CM, Twomlow S, (Lini) Wollenberg E. Urgent action to combat climate change and its impacts (SDG 13): transforming agriculture and food systems. Curr Opin Environ Sustain. 2018;34:13-20. doi: 10.1016/j.cosust.2018.06.005

21. Burford G, Tamás $\mathrm{P}$, Harder MK. Can We Improve Indicator Design for Complex Sustainable Development Goals? A Comparison of a Values-Based and Conventional Approach. Sustainability. 2016;8:861. doi: $10.3390 /$ su8090861

22. Ntona M, Morgera E. Connecting SDG 14 with the other Sustainable Development Goals through marine spatial planning. Mar Policy. 2018;93:21422. doi: 10.1016/j.marpol.2017.06.020

23. Hall RP, Ranganathan S, GC RK. A General Micro-Level Modeling Approach to Analyzing Interconnected SDGs: Achieving SDG 6 and More through MultipleUse Water Services (MUS). Sustainability. 2017;9:314. doi: 10.3390/su9020314

24. Mair S, Jones A, Ward J, Christie I, Druckman A, Lyon F. A Critical Review of the Role of Indicators in Implementing the Sustainable Development Goals. In: Leal Filho W, editor. Handbook of Sustainability Science and Research. World Sustainability Series. Cham (Switzerland): Springer; 2017. doi: 10.1007/978-3-319-63007-6_3

25. McCollum D, Gomez Echeverri L, Busch S, Pachauri S, Parkinson S, Rogelj J, et al. Connecting the Sustainable Development Goals by their energy interlinkages. Laxenburg (Austria): IIASA; 2017. IIASA Working Paper WP-17-006. Available from: http://pure.iiasa.ac.at/id/eprint/14567/. Accessed 2019 Sep 26.

26. Nilsson M, Griggs D, Visbeck M, Ringler A. A draft framework for understanding SDG interactions. Paris (France): International Council for Science; 2016.

27. Nilsson M, Griggs D, Visbeck M. Policy: Map the interactions between Sustainable Development Goals. Nature. 2016;534:320-2. doi: 10.1038/534320a

28. Bowen KJ, Cradock-Henry NA, Koch F, Patterson J, Häyhä T, Vogt J, et al. Implementing the "Sustainable Development Goals": towards addressing three key governance challenges-collective action, trade-offs, and accountability. Curr Opin Environ Sustain. 2017;26-27:90-6. doi: 10.1016/j.cosust.2017.05.002

29. Pradhan P, Costa L, Rybski D, Lucht W, Kropp JP. A Systematic Study of Sustainable Development Goal (SDG) Interactions: A SYSTEMATIC STUDY OF SDG INTERACTIONS. Earth's Future. 2017. doi: 10.1002/2017ef000632

30. Breuer A, Janetschek H, Malerba D. Translating Sustainable Development Goal (SDG) Interdependencies into Policy Advice. Sustainability. 2019;11:2092. doi: 10.3390/su11072092

31. Blanc DL. Towards Integration at Last? The Sustainable Development Goals as a Network of Targets. Sustain Dev. 2015;23:176-87. doi: 10.1002/sd.1582

32. Spangenberg JH. Hot Air or Comprehensive Progress? A Critical Assessment of the SDGs. Sustain Dev. 2017;25:311-21. doi: 10.1002/sd.1657

33. Niestroy I. How are we getting ready? The 2030 Agenda for Sustainable Development in the EU and Its Member States: Analysis and Action So Far. 
Bonn (Germany): Deutsches Institut für Entwicklungspolitik gGmbH; 2016. Discuss Paper 92016.

34. Kettner C, Kletzan-Slamanig D, Köppl A, Littig B, Zielinska I. Monitoring Sustainable Development: Climate and Energy Policy Indicators. Vienna (Austria): WIFO; 2018.

35. OECD. Aggregated Environmental Indices. Review of Aggregation Methodologies in Use. Paris (France): OECD; 2002.

36. OECD. Handbook on constructing composite indicators: methodology and user guide. Paris (France): OECD; 2008.

37. Wroblewski A, Kelle U, Reith F, editors. Gleichstellung messbar machen: Grundlagen und Anwendungen von Gender- und Gleichstellungsindikatoren. Vienna (Austria): VS Verlag für Sozialwissenschaften; 2017. Available from: https://www.springer.com/de/book/9783658132361. Accessed 2019 Sep 26. German.

38. Meyer W. Einführung in die Grundlagen der Entwicklung von Indikatoren. In Gleichstellung messbar machen. Wiesbaden (Germany): Springer Fachmedien Wiesbaden; 2017. German.

39. Griessler E, Littig B. Social sustainability: a catchword between political pragmatism and social theory. Int J Sustain Dev. 2005;8:65-79.

40. Cohen MG. Introduction. Why gender matters when dealing with climate change. Climate Change and Gender in Rich Countries Work, Public Policy and Action. New York (US): Cohen, M.G.; 2017. p. 3-18.

41. Gender Statistics. Available from: https://unstats.un.org/unsd/gender/timeuse/. Accessed 2019 Sep 26.

42. STATISTIK AUSTRIA. Available from: https://www.statistik.at/web de/ statistiken/menschen und gesellschaft/soziales/zeitverwendung/zeitverwen dungserhebung/index.html. Accessed 2019 Sep 26.

43. Davidsdottir B, Basoli DA, Fredericks S, Enterline CL. Measuring sustainable energy development with a three-dimensional index. In: Frontiers in Ecological Economic Theory and Application. Cheltenham (UK): Edward Elgar Publishing; 2007. p. 303-30. Available from: https://www.e-elgar.com/shop/ frontiers-in-ecological-economic-theory-and-application. Accessed 2019 Aug 14.

44. Ibarrarán Viniegra ME, Davidsdottir B, Gracida Zurita R. Índice de sustentabilidad energética: estimaciones para México. Princ Estud Econ Política. 2009;85-100. German.

45. Kettner C, Kletzan-Slamanig D, Köppl A. Assessing Energy Scenarios for Austria with the ISED-AT Framework. WIFO Working Papers. Vienna (Austria): WIFO; 2015. Report No.: 496. Available from: https://www.econstor.eu/handle/10419/129045. Accessed 2019 Aug 14.

46. Greco S, Ishizaka A, Tasiou M, Torrisi G. On the Methodological Framework of Composite Indices: A Review of the Issues of Weighting, Aggregation, and Robustness. Soc Indic Res. 2019;141:61-94. doi: 10.1007/s11205-017-1832-9

47. Andersen MS, Ekins P, editors. Carbon-Energy Taxation: Lessons from Europe. Oxford (UK): Oxford University Press; 2009.

48. Calmfors L, Hassler J, Nasiritousi N, Bäckstrand K, Silbye F, Birch Sørensen P, et al. Climate Policies in the Nordics-Nordic Economic Policy Review 2019. 
Copenhagen (Denmark): Nordisk Ministerråd; 2019. doi: 10.6027/Nord2019012

49. Enevoldsen MK, Ryelund AV, Andersen MS. Decoupling of industrial energy consumption and $\mathrm{CO}_{2}$-emissions in energy-intensive industries in Scandinavia. Energy Econ. 2007;29:665-92.

50. Brännlund R, Lundgren T, Marklund P-O. Carbon intensity in production and the effects of climate policy-Evidence from Swedish industry. Energy Policy. 2014;67:844-57. doi: 10.1016/j.enpol.2013.12.012

51. Pardo Martínez CI, Silveira S. Energy efficiency and $\mathrm{CO}_{2}$ emissions in Swedish manufacturing industries. Energy Effic. 2013;6:117-33. doi: 10.1007/s12053012-9159-5

52. Eurostat. Available from: https://ec.europa.eu/eurostat/tgm/table.do?tab=table \&init=1\& language $=$ en \&pcode=sdg 05 30\&plugin=1. Accessed 2019 Sep 26.

53. The Global Gender Gap Report 2018. Cologny (Switzerland): World Economic Forum; 2018. Available from: https://www.weforum.org/reports/the-globalgender-gap-report-2018/. Accessed 2019 Jun 28.

54. Numhauser-Henning A. The policy on gender equality in Sweden. Brussels (Belgium): Directorate-General for Internal Policies, European Parliament; 2015. Available from: http://www.europarl.europa.eu/RegData/etudes/STUD/ 2015/510011/IPOL STU(2015)510011_EN.pdf. Accessed 2019 Oct 8.

55. Monschauer Y, Kotin-Förster S. Bonus-Malus Vehicle Incentive System in France Fact sheet. Berlin (Germany): Ecofys; 2016.

56. IEA. Energy Policies of IEA Countries: France 2016 Review. Paris (France): IEA; Available from: https://webstore.iea.org/energy-policies-of-iea-countriesfrance-2016-review. Accessed 2019 May 16.

57. Szulecki K. Poland's Renewable Energy Policy Mix: European Influence and Domestic Soap Opera. Rochester (US): Social Science Research Network; 2017 Apr. Report No.: ID 2964866 Available from: https://papers.ssrn.com/abstract=2964866. Accessed 2019 May 16.

58. ENSOLPOL. ENSPOL Report on Existing and Planned EEOs in the EU-Part I: Evaluation of Existing Schemes. Groningen (The Netherlands): JIN Climate and Sustainability; 2015.

59. Surmeli-Anac N, Kotin-Förster S, Schäfer M. Energy Efficiency Obligation Scheme in Denmark Fact Sheet. Berlin (Germany): Ecofys und adelphi; 2018.

60. IEA. Denmark 2017 Review. Energy Policies of IEA countries. Paris (France): IEA; 2017.

61. The Danish Government. The Danish Climate Policy Plan Towards a low carbon society. Copenhagen (Denmark): The Danish Government; 2013. Available from: https://ens.dk/sites/ens.dk/files/Analyser/danishclimatepolicyplan uk.pdf. Accessed 2019 May 16.

62. Sovacool BK. Contestation, contingency, and justice in the Nordic low-carbon energy transition. Energy Policy. 2017;102:569-82.

63. Swedish Environmental Protection Agency. Available from: http://www.naturvardsverket.se/klimatutslapp. Accessed 2019 Sep 26.

64. Swedish Environmental Protection Agency. Greenhouse gas emissions and removals. Stockholm (Sweden): SCB; 2018.

65. Abrell J, Kosch M, Rausch S. Impacts of the UK carbon price floor: A machine learning approach. Zurich (Switzerland): ETH Zürich; 2018. 
66. Baranzini A, van den Bergh JCJM, Carattini S, Howarth RB, Padilla E, Roca J. Carbon pricing in climate policy: seven reasons, complementary instruments, and political economy considerations. Wiley Interdiscip Rev Clim Change. 2017;8:e462. doi: 10.1002/wcc.462

67. Martin R, de Preux L, Wagner U. The impact of a carbon tax on manufacturing: Evidence from microdata. J Public Econ. 2014;117:1-14.

68. Murray B, Rivers N. British Columbia's revenue-neutral carbon tax: A review of the latest "grand experiment" in environmental policy. Energy Policy. 2015;86:674-83. doi: 10.1016/j.enpol.2015.08.011

69. IEA. Energy Policies of IEA Countries: Sweden 2019 Review. Paris (France): IEA; 2019. Available from: https://webstore.iea.org/energy-policies-of-ieacountries-sweden-2019-review. Accessed 2019 Sep 26.

70. IEA. Sweden 2013 Review. Energy Policies of IEA Countries. Paris (France): IEA; 2013.

71. Karakosta C, Pappas C, Marinakis V, Psarras J. Renewable energy and nuclear power towards sustainable development: Characteristics and prospects. Renew Sustain Energy Rev. 2013;22:187-97.

72. Worldbank and Ecofys. State and Trends of Carbon Pricing 2018. Washington (US): Worldbank and Ecofys; 2018.

73. Légifrance. LOI $\mathrm{n}^{\circ}$ 2015-992 du 17 août 2015 relative à la transition énergétique pour la croissance verte - Article 1. Paris (France): Légifrance; 2015. French.

74. IEA. Poland 2016 Review. Energy Policies of IEA Countries. Paris (France): IEA; 2016.

75. Euracoal. Poland country profile. 2017. Available from: https://euracoal.eu/info/country-profiles/poland/. Accessed 2019 Apr 23.

76. European Parliament. Climate and energy policies in Poland. Strassbourg (France): European Parliament; 2017. p. 12. Available from: http://www.europarl.europa.eu/RegData/etudes/BRIE/2017/607335/IPOL BRI(2 017)607335 EN.pdf. Accessed 2019 Apr 23.

77. European Commission. Commission Staff Working Document, Country Report Poland 2015. Bruxelles (Belgium): European Commission; 2015.

78. Tchórzewski K. Polska odrzuca dekarbonizację. Będziemy szli własnym tempem. $\quad$ BiznesAlert. $2016 . \quad$ Available from: https://biznesalert.pl/tchorzewski-polska-odrzuca-dekarbonizacje-bedziemyszli-wlasnym-tempem/. Accessed 2019 May 16. German.

How to cite this article:

Kettner C, Kletzan-Slamanig D, Köppl A, Littig B, Zielinska I. A Cross-Country Comparison of Sustainable Energy Development in Selected EU Members. J Sustain Res. 2019;1:e190017. https://doi.org/10.20900/jsr20190017 